\title{
LUGARES PERSISTENTES, PRÁTICAS FUNERÁRIAS E TECNOLOGIA CERAMISTA EM CAÇADORES-COLETORES PRÉ-HISTÓRICOS SUL-AMERICANOS Uma Proposta de Interpretação para o Sítio Arqueológico Pedra do Alexandre, Carnaúba dos Dantas, RN, Brasil
}

\section{PERSISTENT PLACES, FUNERARY PRACTICES AND CERAMIC TECHNOLOGY IN SOUTH AMERICAN PREHISTORIC HUNTERS-COLLECTORS}

An Interpretation Proposal for the Archaeological site Pedra do Alexandre, Carnaúba dos Dantas, RN, Brazil

\author{
Fabio Mafra ${ }^{1}$ \\ fabiomafraborges@gmail.com
}

\begin{abstract}
RESUMO
A classificação do sítio Pedra do Alexandre como cemitério, insere-o no cerne das discussões sobre as práticas funerárias de grupos caçadores-coletores sul-americanos. Considerado como lugar persistente (persistente place) e marco paisagístico (landmark), neste artigo, apresentou-se uma síntese das pesquisas arqueológicas desenvolvidas. Como resultados obtidos, elenca-se: as novas cronologias definidas, as relações tecno-tipológicas com os outros sítios registrados e o surgimento da tecnologia ceramista, no assentamento. Além da proposição de um modelo de variação temporal para as práticas mortuárias e a definição de um horizonte cultural, com longa duração histórica, na área arqueológica do Seridó (RN, Brasil).
\end{abstract}

Palavras-chave: Práticas Funerárias - Persistent Place - Grupos caçadores-coletores ceramistas

\footnotetext{
${ }^{1}$ Departamento de História, Universidade Federal do Rio Grande do Norte.
} 


\begin{abstract}
The classification of the Pedra do Alexandre site as a cemetery inserts it at the heart of the discussions on the funerary practices of South American hunter-gatherer groups. Considered as a persistent place and a landmark, this article presents a synthesis of the archaeological research developed. As results obtained, it is listed: the new defined chronologies, the techno-typological relations with the other registered sites and the emergence of ceramic technology in the settlement. In addition to the proposition of a model of temporal variation for mortuary practices and the definition of a cultural horizon, with a long historical duration, in the archaeological area of Seridó (RN, Brazil).
\end{abstract}

Key-words: Funerary Practices - Persistent Place - Hunter-gatherer ceramists groups

\title{
CONTEXTO DA PESQUISA
}

O estudo arqueológico das práticas mortuárias de grupos caçadores-coletores préhistóricos sul-americanos evidenciou uma grande variação temporal, regional, cultural e tipológica (STRAUSS, 2010). No entanto, foi possível delimitar três categorias de inumação, que perpassam a maioria dos horizontes culturais estabelecidos: (a) enterramentos primários, (b) enterramentos secundários e (c) a cremação $^{2}$ (BINFORD, 1971; BIRD, 1988). Nesse sentido, pode-se afirmar que as práticas mortuárias de grupos caçador-coletores da pré-história sul-americana são

\footnotetext{
${ }^{2}$ Como enterramentos primários, caracterizam-se as deposições funerárias simples, com esqueletos anatomicamente articulados, com pouco ou nenhum acompanhamento fúnebre. Por sua vez, os enterramentos secundários consistem naqueles em que ocorre a manipulação/redução intencional dos corpos, para a realização de um segundo sepultamento; através da individualização, da realocação ou da deposição em feixe dos ossos. Já a cremação, que se configuram como prática mortuária amplamente difundida a partir do Holoceno Médio (STRAUSS, 2010), consiste na redução pelo fogo dos restos mortais e pode ser o resultado de uma gama de processamentos funerários, tanto perimortem, como em contextos de secundarização.
} 
caracterizadas pelo descarte dos mortos em espaços domésticos e/ou áreas especializadas, mediante a transformação dos corpos, tanto pela cremação como pela secundarização, associados à enterramentos primários simples e com baixo índice de acompanhamento funerário. Esta diversidade tipológica presente é verificada, inclusive, em horizontes culturais comuns (SANTORO et al., 2005).

Denominados de Arqueologia da Morte ou das Práticas Mortuárias (RIBEIRO, 2007), estes estudos têm estabelecido - através de aportes da Teoria de Sistemas, Teoria dos Papeis Sociais e Análise Componencial - uma dinâmica relacional entre as tradições funerárias e a organização social (BINFORD, 1971). Utilizando-se de categorias analíticas como Identidade Social, Relação de Identidade e Persona Social foi proposto que, uma maior complexidade das práticas mortuárias seria um indicativo de hierarquia nas relações sociais e do status social do indivíduo sepultado (SAXE, 1970).

Nesse sentido, em sociedades igualitárias de tipo caçadora-coletora haveria uma nítida diferença no tratamento funerário de indivíduos subadultos - com pouca ou nenhuma identidade social - em relação àqueles dispensados para indivíduos adultos e socialmente ativos. Em outras palavras, quanto mais influente a persona social, maior a diferenciação categórica das práticas mortuárias. Ressaltando-se nesta situação, o tratamento dos cadáveres mediante secundarização, que se caracteriza por um investimento energético mais alto (TAINTER, 1980, 1981). 
Outro aspecto relevante para o estudo das práticas mortuárias de sociedades caçador-coletoras é a identificação de áreas especializadas para a realização de inumações: o problema da definição/delimitação de cemitérios formais. Através de uma lógica indutiva proveniente de paralelos etnográficos, Saxe (1970) propôs que, o estabelecimento de cemitérios formais, estaria vinculado a um aumento da competição de recursos vitais e a formação de grupos corporativos hereditários, além de indicar processos de sedentarização e controle de fronteiras territoriais. Assim, a exclusividade funcional de áreas cemiteriais permitiria a segregação entre sociedades caçador-coletoras e tribais, utilizando as práticas mortuárias como indicadores de padrões de subsistência. Logo, o padrão de mobilidade dos caçadorcoletores condicionaria um oportunismo na escolha das áreas de deposição dos restos mortais de seus indivíduos, com a predominância de inumações no interior do espaço doméstico (CHARLES \& BUIKSTRA, 1983).

Por sua vez, o registro arqueológico sulamericano tem demonstrado a existência de áreas de sepultamento formais, mesmo em contextos caçador-coletores com alta mobilidade territorial. Esta incompatibilidade em relação aos dados etnográficos pode ser um viés analítico decorrente da situação marginal, com alta competição territorial e de recursos, na qual se encontravam os grupos culturais, analisados na atualidade (STRAUSS, 2010). Esta situação, tanto etnográfica como histórica, condicionou uma dicotomia radical entre os conceitos de sedentarização e nomadismo, a qual quase nunca é verificada em contextos pré-históricos e/ou arqueológicos. 
Através da análise da mobilidade espacial de grupos caçadores-coletorespescadores, Binford (1980) identificou dois tipos de manejo territorial: (a) mobilidade residencial e (b) mobilidade logística ${ }^{3}$. Apropriando-se desses conceitos de mobilidade espacial, Walthall (1999) propõe uma tipologia para as práticas mortuárias de grupos caçador-coletores, mediante a delimitação de dois modelos: (1) modelo do depósito expedito, relacionado ao padrão de mobilidade residencial; (2) modelo de depósito em lugares especiais, relacionado ao padrão de mobilidade logística.

Entretanto, estas proposições mantêm o foco em processos de sedentarização, já que o padrão de mobilidade logística se configura pelo deslocamento anual, em um território de fronteiras relativamente fixas. Além disso, mantêm a vinculação com a estabilidade e a baixa competição por recursos naturais (SAXE, 1970). Logo, a exclusividade funcional para a delimitação de cemitérios formais, ainda é fator condicionante para seu reconhecimento no registro arqueológico. Não mais como indicador de desenvolvimento sócio cultural, tendo em vista que, o número de abrigos rochosos com deposições funerárias, ou sítios-cemitérios em contextos caçador-coletores, aumenta progressivamente com o desenvolvimento das

\footnotetext{
${ }^{3}$ Sociedades que apresentam padrão de mobilidade do tipo residencial, tendem a descolocar o acampamento principal para áreas com recursos disponíveis, em territórios com fronteiras não definidas, caracterizando-se por uma intensa mobilidade. Por sua vez, a mobilidade logística caracterizaria grupos culturais com manejo de um território com estabilidade de recursos naturais, ao longo do ciclo anual, o qual permitiria a delimitação de áreas de exploração, anexadas ao um território de manejo cultural, com fronteiras definidas: território de domínio.
} 
pesquisas arqueológicas (MARTIN, 2008; PROUS, 1992; STRAUSS, 2010). Mas, pelo menos, como ferramenta de análise para classificação destes tipos de assentamentos pré-históricos, através da definição de perfis funerários e sistematização de dados antropométricos e tafonômicos (ALVIM et al., 1995-1990; ALVIM et al., 1990; SOLARI et al., 2016).

A principal característica do registro arqueológico evidenciado em assentamentos funcionalmente classificados como cemitérios, é a reocupação por longos intervalos temporais, deste mesmo espaço, por um ou vários grupos culturais (MARTIN, 2008; PROUS, 1992; STRAUSS, 2010). Geralmente utilizados como acampamentos temporários e áreas para a realização de atividades gráficas e práticas mortuárias, a ausência de uma exclusividade funcional, contudo, não permite a caracterização objetiva de um cemitério formal. Em outras palavras, a acumulação não intencional de modelos de depósito expeditos, às vezes ao longo de milhares de anos, pode levar a falsa identificação de um modelo de depósito em lugares especiais (WALTHALL, 1999).

Logo, a análise de abrigos rochosos utilizados para a deposição de mortos, por grupos de caçador-coletores pré-históricos, não permite a identificação objetiva de cemitérios formais. Por sua vez, a não exclusividade funcional, não nega a formalização de um espaço funerário (BRANDT, 1988). O conjunto de procedimentos técnicos, as práticas sociais e os comportamentos simbólicos que constituem a complexidade dos rituais funerários, nos mais diversos horizontes 
culturais, integram outros tipos de comportamento sociais às práticas mortuárias, que entram em choque com a exclusividade funcional prevista.

Dessa maneira, mostrou-se imperiosa a necessidade de definição de critérios para a identificação arqueológica de cemitérios, em sítios caçador-coletores: (a) o número mínimo de indivíduos ( $\geq 1$ enterramento); (b) densidade mínima; (c) fronteira espacial delimitada; (d) exclusividade funcional; (e) reocupação funcional, por longo intervalo de tempo; (f) recorrência formal nos enterramentos (LITTLETON, 2002; PARDOE, 1988). Logo, antes de definir cemitérios formais, estes critérios permitem identificar "persistent places"4. Ou seja, lugares com qualidades que (a) favorecem a função funerária, (b) estimulam a reocupação por longos intervalos temporais e (c) se destacam na paisagem como pontos notáveis (landmarks) referências paisagísticas (LITTLETON \& ALLEN, 2007).

Nos mais diversos aspectos, o sítio arqueológico Pedra do Alexandre se insere no centro desta discussão teórico-metodológica. Localizado no município de Carnaúba dos Dantas-RN, na área arqueológica do Seridó (Figura 01), caracteriza-se como um abrigo em rocha metamórfica (micaxisto), com a presença de registros rupestres pintados e gravados, em sua maioria vinculados à Tradição Nordeste, Subtradição Seridó (MARTIN, 2008). Em seu pacote estratigráfico, foram evidenciados enterramentos primários e secundários, com ou sem acompanhamento funerário,

\footnotetext{
${ }^{4}$ Lugares persistentes (tradução livre).
} 
datados entre \pm 9200 anos AP e 2620 anos AP (ALVIM et al., 1995-1996; ALVIN et al., 1990; MARTIN, 2008, 1996, 1995-1996, 1994; SANTOS JR., 2013; SOLARI et al., 2016) (Tabela 01) (Figura 02). As últimas campanhas arqueológicas realizadas (2010-2011), no entanto, permitiram o recuo desta cronoestratigrafia para \pm 11000 A.P. (mediante calibração do $C^{14}$ ) (Tabela 02). Este fator permite o reconhecimento, do sítio em questão, como um "lugar persistente", apesar de sua classificação tipológica como sítio-cemitério, na bibliografia especializada.

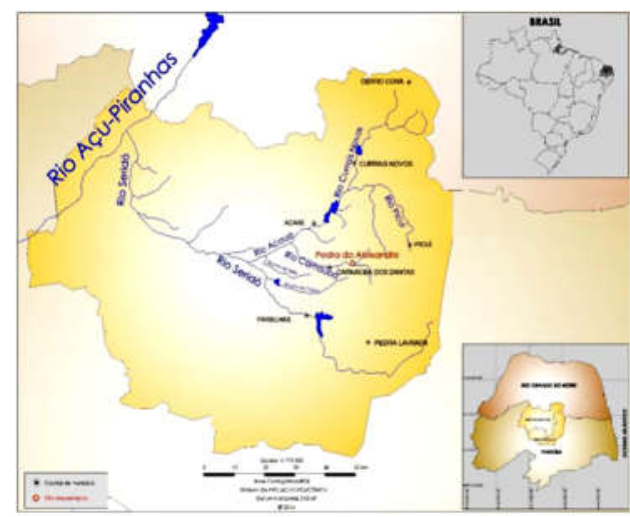

Figura 01 - Mapa com a localização do sítio Pedra do Alexandre, Carnaúba dos Dantas-RN, Brasil. (Fonte: SOLARI et al., 2016).

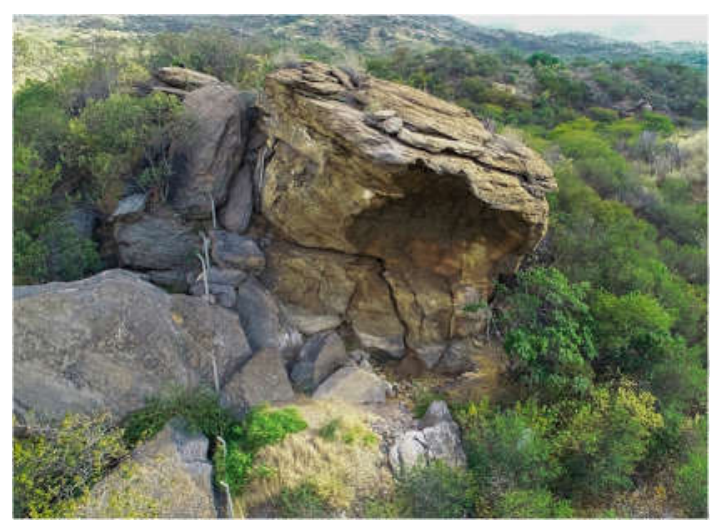

Figura 02 - Vista geral do abrigo. Sítio Pedra do Alexandre, Carnaúba dos Dantas, RN, Brasil. (Fonte: Lucas E. S. de Medeiros, 2020). 


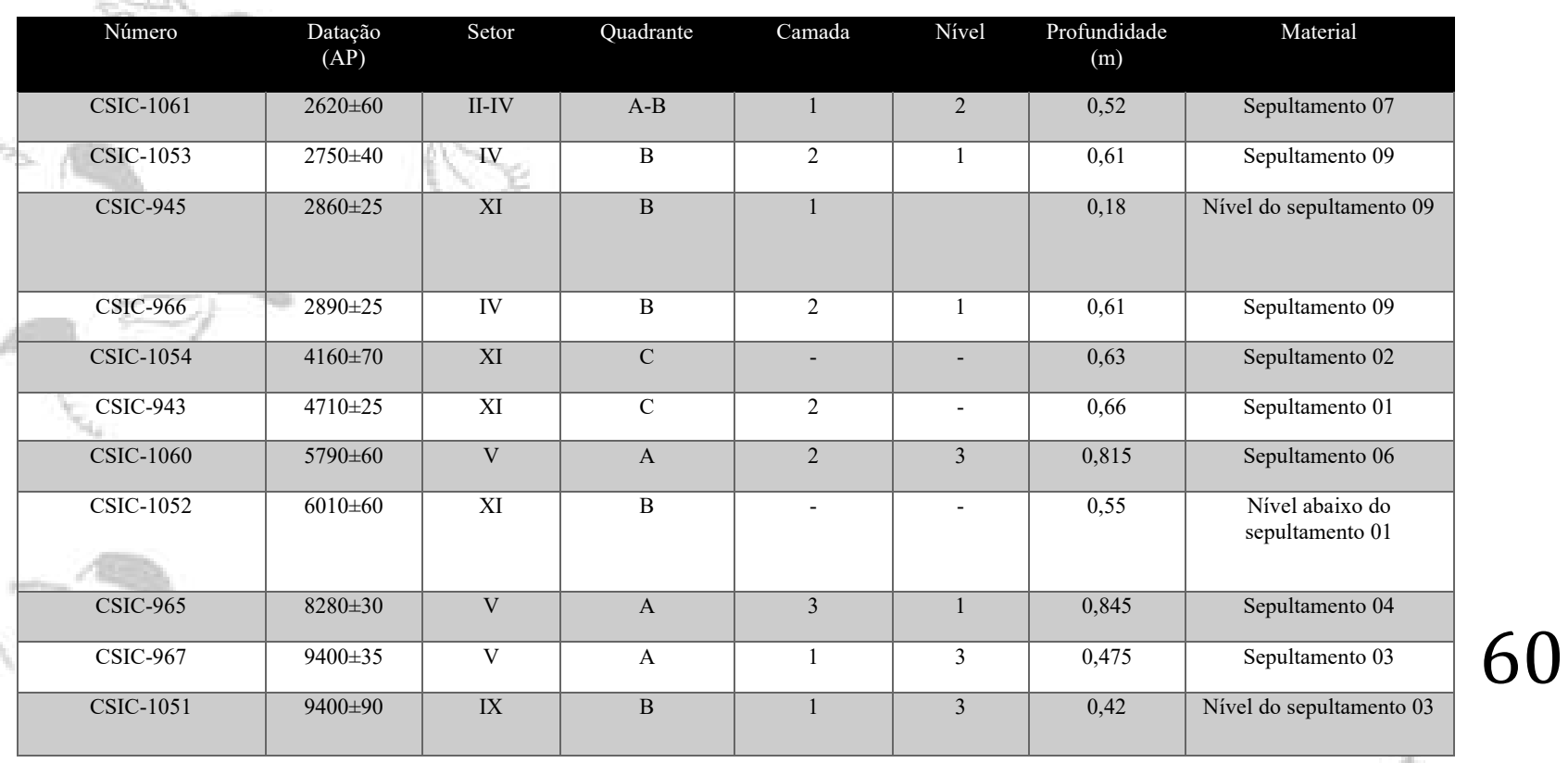

Tabela 01 - Tabela de datações radio carbônicas para o sítio arqueológico Pedra do Alexandre, Carnaúba dos Dantas, RN, Brasil. (Fonte: MARTIN, 2008; MUTZENBERG, 2007).

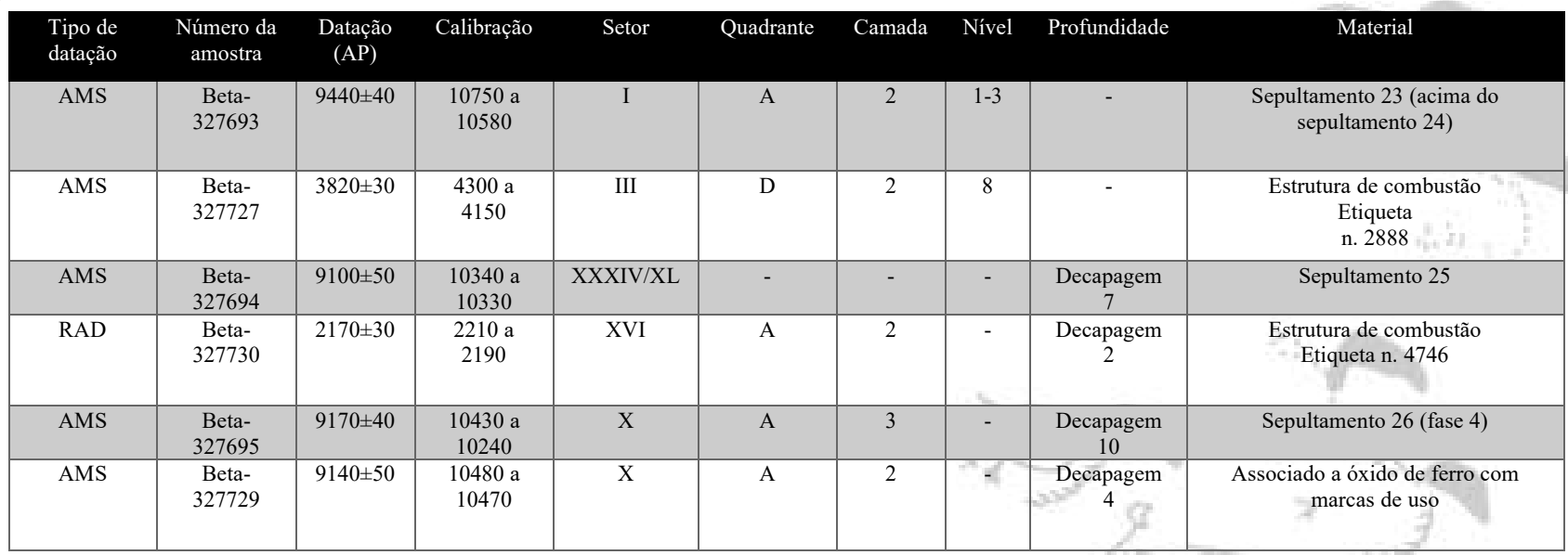

Tabela 02 - Tabela com as datações radio carbônicas inéditas - XVI e XVII Campanha arqueológica. Sítio arqueológico Pedra do Alexandre, Carnaúba dos Dantas, RN, Brasil. 
Entre os anos de 1990 e 2011, foram realizadas dezessete (17) campanhas arqueológicas, que permitiram a exumação de vinte e quatro (24) deposições funerárias com número mínimo de quarenta e oito indivíduos $(\mathrm{NMI}=48)^{5}$, distribuídas em três (03) níveis de ocupação, com a presença de estruturas de combustão, remanescentes floro-faunísticos, material lítico lascado e polido e material cerâmico (Figura 03). Este conjunto de estruturas e vestígios arqueológicos favoreceu sua utilização como parâmetro para classificação cronocultural e a proposição de rotas de povoamento utilizadas pelos grupos autores dos registros rupestres, catalogados na área arqueológica do Seridó (MARTIN, 2008, 1994, 1995-1996; MUTZENBERG, 2007; SOLARI et al., 2016).

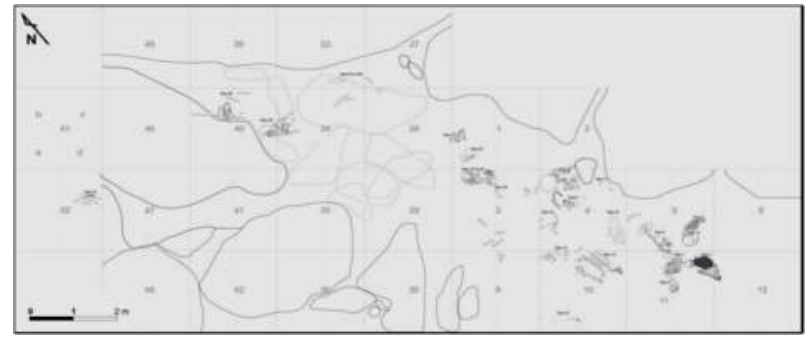

Figura $03-$ Planta-baixa de representação da distribuição espacial dos enterramentos do sítio arqueológico Pedra do Alexandre, Carnaúba dos Dantas-RN, Brasil. (Fonte: SOLARI et al., 2016).

As análises antropométricas, forenses e tafonômicas em desenvolvimento permitiram identificar um número mínimo de indivíduos (NMI) de vinte e cinco (25) indivíduos subadultos, entre perinatos, crianças e jovens. Estes enterramentos infantis $(\mathrm{NMI}=25)$, como idiossincrasia do sítio em questão, receberam o mesmo

${ }^{5}$ Dados atualizados, após segunda revisão da reserva técnica do LABIFOR-UFPE (SILVA et al., 2020). 
tratamento dispensado para os indivíduos adultos $(\mathrm{NMI}=23)$ : tanto quanto aos tipos de inumação realizados - enterramentos primários ou em contexto de secundarização - como quanto aos espaços de sepultamento utilizados (SOLARI et al., 2016). Apesar da impossibilidade de definição de um perfil funerário para o sítio Pedra do Alexandre, o alto número de enterramentos de subadultos, no mesmo espaço e em contextos de secundarização, é bastante significativo para um assentamento com funções funerárias, relacionado a grupos de caçadores-coletores pré-históricos. Principalmente a luz das discussões teóricas supracitadas, que relaciona status e persona social, ao grau de energia dispensado em um conjunto de práticas mortuárias (BINFORD, 1971; SAXE, 1970; STRAUSS, 2010).

Em momento anterior, foi proposta a definição de três (03) intervalos cronológicos de práticas mortuárias: o primeiro entre \pm 9400 anos AP a \pm 8280 anos AP; o segundo entre \pm 5790 anos AP e \pm 4160 anos AP; o terceiro, que apresentou uma pequena variação morfológica nos tipos de sepultura - ausência de covas delimitadas por blocos de pedra - entre \pm 2890 anos AP e \pm 2620 anos AP (SANTOS JR., 2013). Contudo, o acréscimo dos dados resultantes das últimas campanhas realizadas - XVI e XVII campanhas arqueológicas (2010-2011) demonstrou que essa periodização precisava ser reformulada, mediante as novas datas estabelecidas e os tipos de inumação evidenciados.

Outro aspecto relevante, diz respeito a sua classificação como sítio-cemitério. Como anteriormente exposto, o conceito de "lugar persistente", considera o espaço 
funerário de um grupo caçador-coletor como um espaço multifuncional, onde predominam as práticas funerárias. Em outras palavras, a realização de práticas funerárias no Pedra do Alexandre não excluiu outras atividades: práticas pictóricas, processamentos de animais de pequeno porte e moluscos univalves, entre outros procedimentos técnicos. Por sua vez, como é comum em assentamentos deste tipo, as análises laboratoriais privilegiaram a definição de perfis funerários, as análises antropométricas e paleopatológicas e as análises tafonômicas nos restos esqueletais humanos exumados (ALVIM et al., 1995-1996; SANTOS, 1997; SOLARI et al., 2016(a) e 2016(b)). Logo, é baixo o índice de publicações que considerem os contextos não funerários e os vestígios arqueológicos associados, que dividem o mesmo espaço do sítio, com as práticas mortuárias (FONTES, 2003; SILVA, 2004; TORRES, 1995-1996).

A identificação de sítios lito-cerâmicos a céu aberto no vale do rio da Cobra Carnaúba dos Dantas e Parelhas-RN (MAFRA et al., 2015, 2016), com cronologias definidas entre \pm 4000 anos AP e \pm 900 anos AP, tem ampliado as classificações crono-culturais na região (NOGUEIRA, 2017). A relação espacial verificada, entre o sítio Pedra do Alexandre, os sítios com registros rupestres e os sítios a céu aberto têm permitido a definição de funcionalidades, para tais espaços selecionados pelos grupos caçador-coletores-ceramistas (BORGES, 2010; NOGUEIRA, 2017). Ademais, a recorrência verificada nas indústrias tecnológicas, lítica e cerâmica, tem sugerido a identificação de um horizonte cultural comum, para ambos os contextos 
espaciais: os sítios abrigados e os sítios lito-cerâmicos (ALMEIDA, 2014; NOGUEIRA, 2017).

O registro de fragmentos cerâmicos em deposição estratigráfica e associação direta com estruturas de combustão datadas, no sítio abrigado Furna do Umbuzeiro - \pm 2700 anos AP (Laboratorio de Geocronologia do Instituto de Química Física "Rocasolano" (CSIC - BORGES, 2010) e no sítio lito-cerâmico Meggers III Parelhas-RN - \pm 2800 anos AP (Beta Analitic - NOGUEIRA, 2017) - proporcionou o recuo de mil anos nas datas estabelecidas para a introdução da tecnologia cerâmica, na área arqueológica do Seridó. A data anterior foi determinada mediante datação relativa de fragmentos cerâmicos, não associados a estruturas funerárias, coletados no sítio Pedra do Chinelo e com idade estimada em \pm 1991 anos AP (CSIC - VIDAL, 2002; FONTES, 2003).

Esta situação direcionou as pesquisas atuais para a solução dos problemas em torno do advento da tecnologia ceramista ${ }^{6}$. Ou seja, permitiu a delimitação de um problema científico, que urge solução para viabilizar a reconstituição dos processos de mudança cultural nesse horizonte caçador-coletor: a adoção e o uso da tecnologia

\footnotetext{
${ }^{6}$ Segundo Brochado (1984), o desenvolvimento de tradições ceramistas regionais, em grupos caçador-coletores sul-americanos se deu através da dispersão da Tradição ceramista Mina, desenvolvida em sambaquis fluviais, na foz do rio Amazonas. Entretanto, esta é uma suposição ainda não foi testada de forma sistemática, mediante a identificação de rotas de transmissão desta inovação tecnológica.
} 
cerâmica se deram mediante (a) a difusão de traços culturais ou através de um (b) desenvolvimento autóctone?

O aparecimento repentino na estratigrafia dos sítios em que este vestígio foi datado - Pedra do Alexandre, Furna do Umbuzeiro e Meggers III - reforça a hipótese que sugere processos de difusão de traços culturais, através de rotas de transmissão desconhecidas. No entanto, advoga-se aqui a fragilidade de dados, para a formulação desta resposta. $\mathrm{O}$ enfoque analítico nas práticas mortuárias e nas rotas de dispersão das tradições rupestres identificadas na região (MARTIN, 2008), não privilegiou estas problematizações, com ênfase nos modos de subsistência e nos processos de mudança cultural.

A reconstituição dos padrões de subsistência, os usos e inovações tecnológicas, os padrões de mobilidade espacial e os processos de mudança cultural na área arqueológica do Seridó, justificam a seleção do Pedra do Alexandre, pelo longo período em que o abrigo foi ocupado e potencial arqueológico verificado. Em outras palavras, os dados arqueológicos possibilitam seu uso como como parâmetro de classificação crono-cultural para outros sítios identificados. Além de viabilizar a proposição de uma resposta plausível ao problema da introdução da tecnologia ceramista e das consequentes mudanças culturais provenientes desta inovação tecnológica, no(s) horizonte(s) cultural(ais) da região. 


\section{INTERVENÇÕES ARQUEOLÓGICAS}

De janeiro de 1990 até novembro de 2011, foram realizadas dezessete (17) campanhas arqueológicas no sítio Pedra do Alexandre. Estas atividades tiveram como objetivo principal, a coleta de dados arqueológicos para a verificação de hipóteses sobre: (a) o processo de povoamento da área arqueológica do Seridó (MARTIN, 2018; MUTZENBERG, 2007), (b) as rotas de dispersão das tradições rupestre registradas e seu relacionamento com a cultura material evidenciada (MARTIN, 1985, 1989, 1993, 1996, 2008; MARTIN e GUIDON, 2010; MARTIN e ASÓN-VIDAL, 2014), (c) a descrição das práticas funerárias realizadas no assentamento e as características bioarqueológicas do conjunto de indivíduos inumados (ALVIM et al., 1990; MARTIN, 1994; MARTIN, 1995-1996; ALVIM et al, 1995-1996; SANTOS, 1997; TORRES, 1995-1996; SILVA, 2003; MARTIN, 2008; BORGES, 2008; CASTRO, 2009; SOLARI et al., 2016(a) 2016(b); SOLARI et al., 2018; SILVA et al., 2020), (d) a definição de enclaves pré-históricos e suas fronteiras culturais (MARTIN, 2003, 2008; MARTIN e ASÓN-VIDAL, 2014; BORGES, 2010; MAFRA et al., 2016), (e) a reconstituição paleoclimática e dos processos de formação de seu depósito sedimentar (MUTZENBERG, 2007) e (f) a definição de uma cronoestratigrafia referencial, que permitisse a caracterização objetiva de outros sítios arqueológicos registrados na região (MARTIN, 2008).

Concomitantemente, foram realizadas prospecções e outras intervenções arqueológicas, ampliando as atividades de pesquisa iniciadas na década de 1980, que forneceram subsídios para a compreensão da (a) distribuição espacial e da 
diversidade tipológica dos registros rupestres (MARTIN, 2003), (b) a definição funcional de assentamentos a céu aberto e em abrigos rochosos e suas relações espaciais (BORGES, 2010; NOGUEIRA, 2017), (c) a definição de perfis técnicos cerâmicos e líticos (ALMEIDA, 2014; NOGUEIRA, 2017), (d) aplicação de aportes metrológicos para definições cronológicas e caracterização de processos tafonômicos e diagenéticos em vestígios arqueológicos (SULLASI et al., 2018).

Localizado a \pm 250 m do rio Carnaúba, em sua margem direita (Figura 04), o Pedra do Alexandre se destaca na paisagem, pela sua dimensão e morfologia (landmark) ${ }^{7}$, proporcionando um espaço habitacional considerável, que foi fator atraente para as populações pré-históricas que habitavam a região (Figura 05). Esta situação é demonstrada pelo longo período de ocupação, no qual o abrigo foi utilizado, tanto para a realização de práticas mortuárias, como práticas gráficas; além é claro, de ocupações sazonais de curta duração, com as mais diversas finalidades. Seu espaço interno, formado pela decomposição do suporte rochoso e a queda de blocos que garantiram a formação do depósito sedimentar, abrange uma área de aproximadamente $200 \mathrm{~m}^{2}$ (Figura 06), onde um paredão vertical de $2 \mathrm{~m}$ de altura o qual serviu de suporte para registros rupestres (MARTIN, 2008) (Figura 07) culmina em um teto com altura máxima de $15 \mathrm{~m}$. Contudo, a disposição dos blocos caídos e as fraturas verificadas na porção oeste do abrigo indicam que o espaço habitável possuía dimensões maiores que as verificadas atualmente, dado o

\footnotetext{
${ }^{7}$ Marcadores paisagísticos, em tradução livre.
} 
desmoronamento parcial do teto (Figura 06). Este fato provocou intensa perturbação nas camadas arqueológicas depositadas e a formação de dois (02) nichos sob grandes blocos que se acomodaram no interior do abrigo, onde novos níveis de ocupação foram identificados (Figura 08).

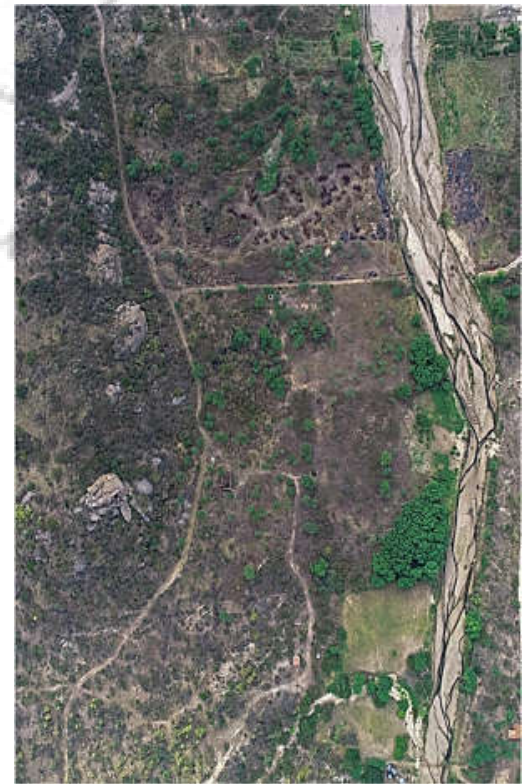

Figura 04 - Vista aérea do sítio arqueológico Pedra do Alexandre, à margem direita do rio Carnaúba. Carnaúba dos Dantas, RN, Brasil. (Fonte: Lucas E. S. de Medeiros, 2020).

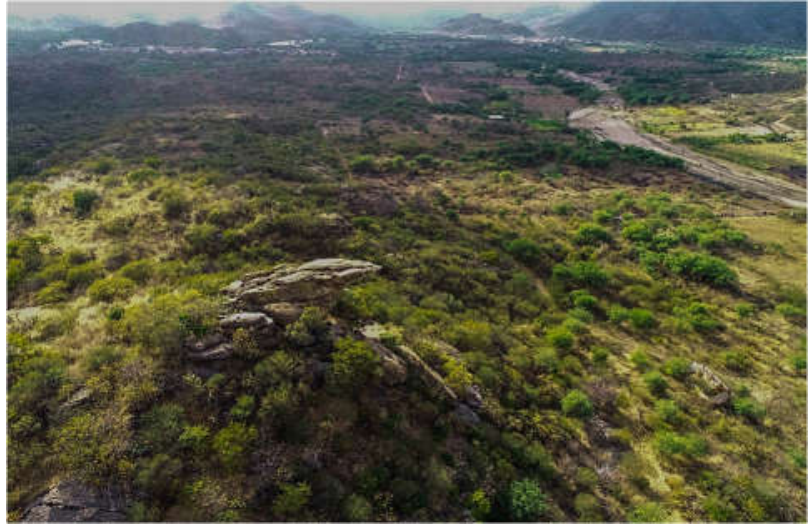

68

Figura 05 - Vista aérea do abrigo rochoso e sua disposição na paisagem (landmark). Sítio arqueológico Pedra do Alexandre, Carnaúba dos Dantas, RN, Brasil. (Fonte: Lucas E. S. de Medeiros, 2020). 


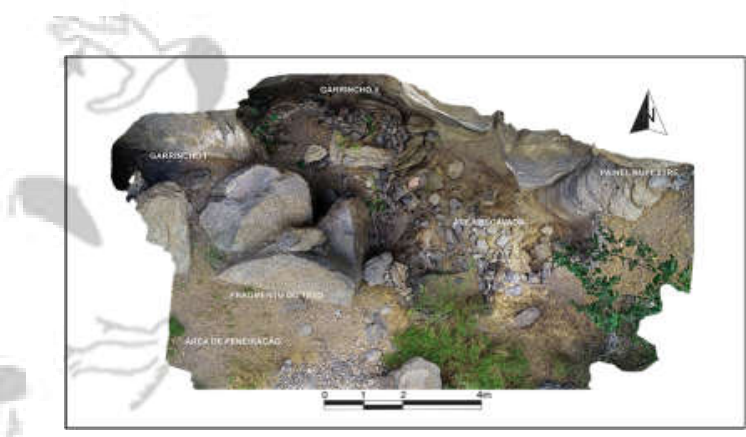

Figura 06 - Planta-baixa em 3D, representando o espaço interno do abrigo rochoso. Sítio arqueológico Pedra do Alexandre, Carnaúba dos Dantas, RN, Brasil. (Fonte: Lucas E. S. de Medeiros e Mizael M. S. da Costa, 2020).

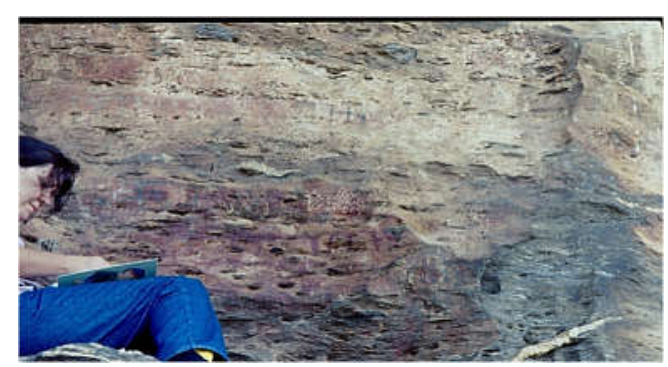

Figura 07 - Vista geral do painel rupestre do sítio arqueológico Pedra do Alexandre, Carnaúba dos Dantas, RN, Brasil. (Fonte: Banco de dados digitais NEA/UFPE).

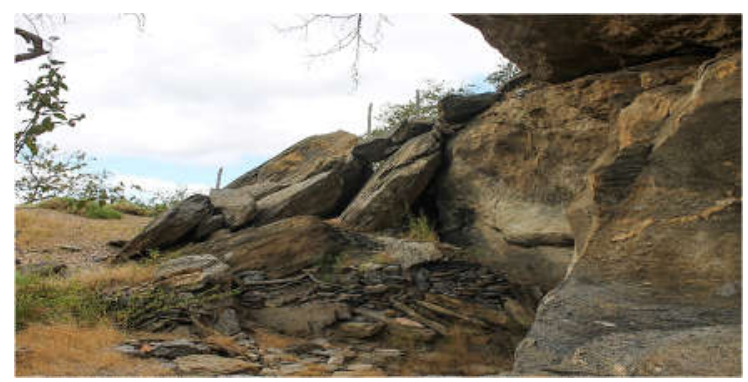

Figura 08 - Vista geral de nicho formado por blocos provenientes do teto desmoronado "Garrincho I" - porção oeste do abrigo. Sítio arqueológico Pedra do Alexandre, Carnaúba dos Dantas, RN, Brasil. (Fonte: Mizael M. S. da Costa, 2020).

Com aproximadamente um terço (1/3) de seu pacote sedimentar escavado, o sítio apresentou diversos níveis arqueológicos, nos quais foram identificadas vinte e quatro (24) estruturas funerárias, distribuídas em inumações primárias, secundárias, individuais e coletivas; além de conjuntos ósseos que indicam antigas estruturas funerárias, alteradas por processos pós-deposicionais. Sobre estas deposições funérias, foram evidenciadas estruturas de combustão sobrepostas, onde foi registrada a presença de fragmentos ósseos humanos e não humanos, fragmentos de 
material lítico e cerâmico, vestígios de práticas pictóricas, entre outros tipos de material arqueológico (Figura 09 e Figura 10). Consideradas como fogueiras rituais relacionadas à liturgia funerária ${ }^{8}$, a situação estratigráfica próxima da superfície (Figura 11), levou a consideração de que estas estruturas estariam perturbadas e seus comburentes (fragmentos de carvão e madeiras) contaminados, para o estabelecimento de cronologias. Esta interpretação, por sua vez, condicionou as técnicas de registro dispensadas nessas estruturas arqueológicas.

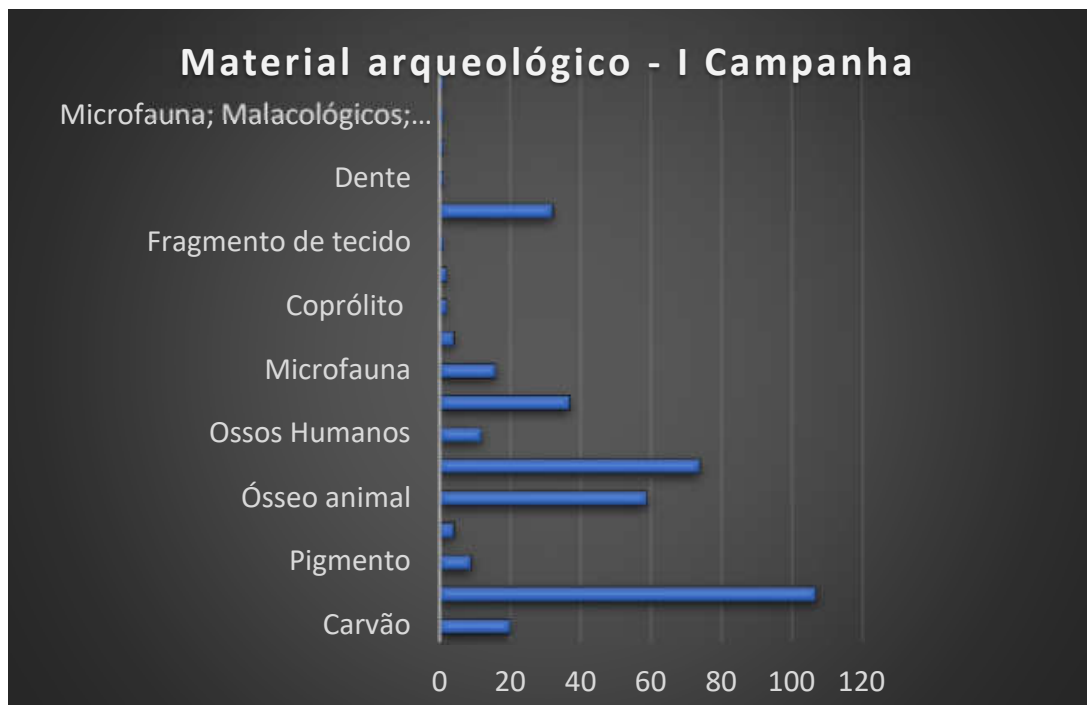

Figura 09 - Gráfico representando os tipos e a quantidade dos vestígios arqueológicos registrados na I Campanha arqueológica realizada no sítio arqueológico Pedra do Alexandre, Carnaúba dos Dantas, RN, Brasil. (Fonte: Banco de dados digitais - NEA/UFPE).

${ }^{8}$ As estruturas de combustão estavam depositadas sobre as estruturas funerárias dos sepultamentos 1 e 2 (MARTIN, com. pess.). 


\section{Material arqueológico - II Campanha}

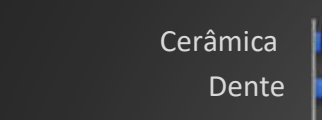

Fragmento de tecido

Sementes

Cropólito

Sedimento

Adorno

Microfauna

Ósseo humano

Ósseo

Ósseo Animal

Malacológico

Pedras

Pigmentos

Lítico

Carvão

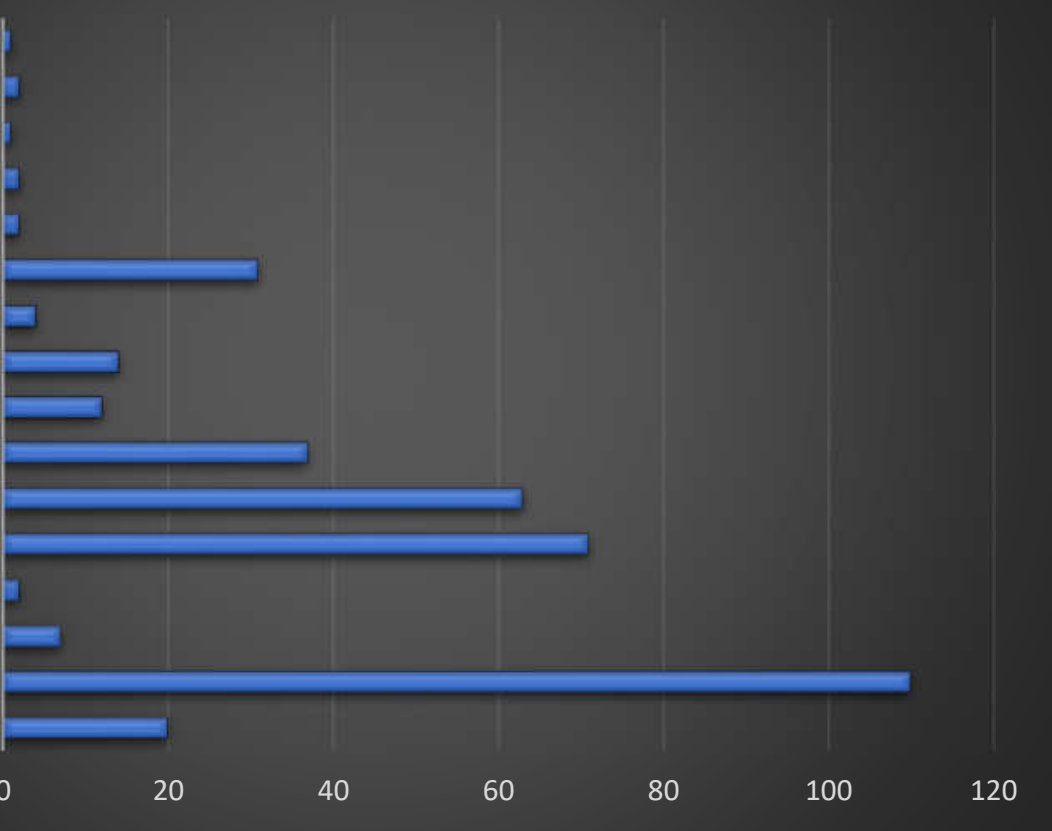

Figura 10 - Gráfico representando os tipos e a quantidade dos vestígios arqueológicos registrados na II Campanha arqueológica realizada no sítio arqueológico Pedra do Alexandre, Carnaúba dos Dantas, RN, Brasil. (Fonte: Banco de dados digitais - NEA/UFPE).

Entretanto, (1) o tipo de estrutura de combustão - composta por fogueiras sobrepostas, em espaços delimitados do abrigo - (2) o registro de fragmentos ósseos humanos, (3) a associação com remanescentes ósseos não humanos, fragmentos cerâmicos e artefatos líticos, entre outros vestígios, relaciona estes dados com aqueles registrados no sítio Furna do Umbuzeiro (Figura 12). 


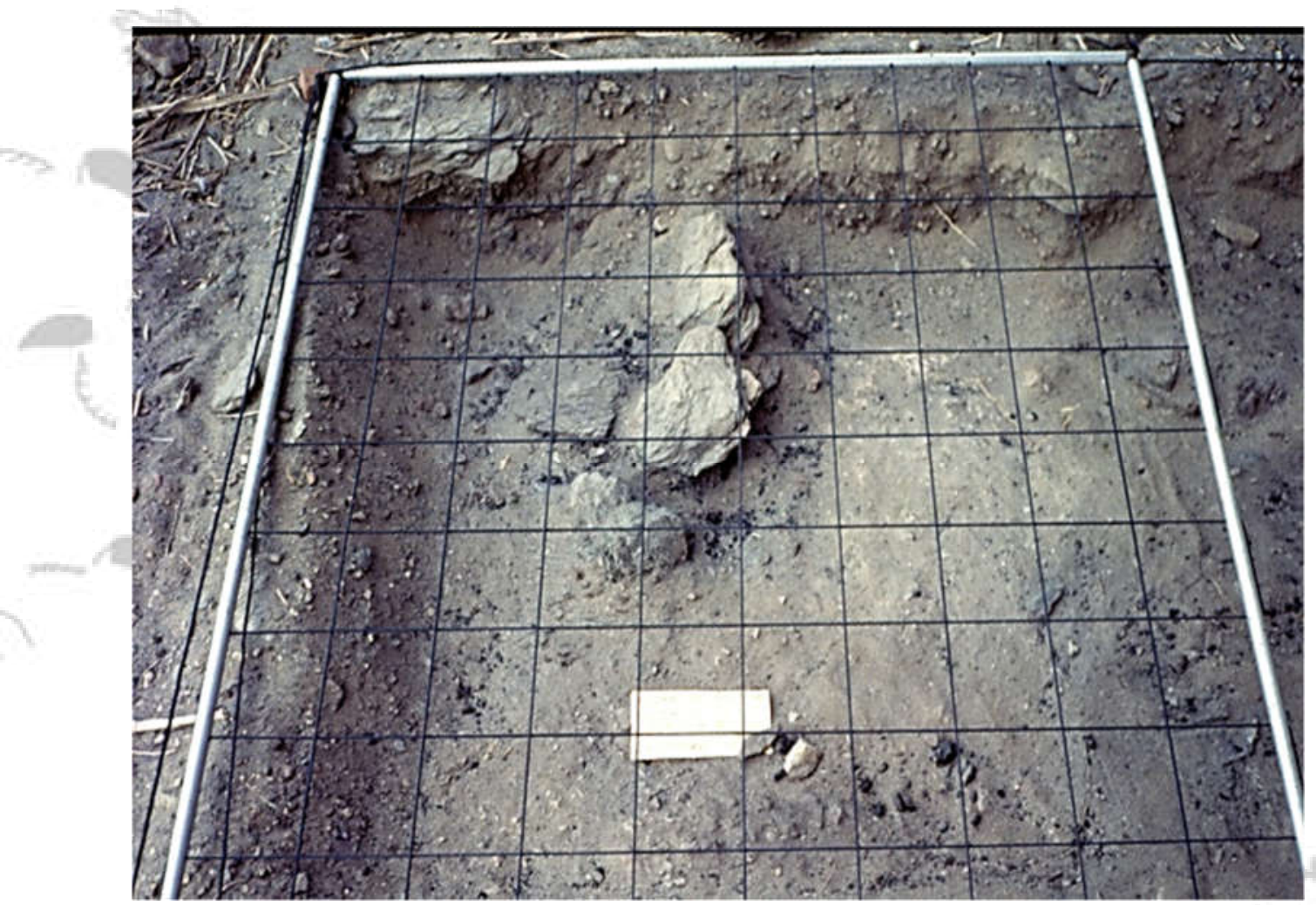

Figura 11 - Estrutura de combustão evidenciada nas primeiras decapagens realizadas - I Campanha - setor I - Sítio arqueológico Pedra do Alexandre, Carnaúba dos Dantas, RN, Brasil. (Fonte: Banco de dados digitais - NEA/UFPE).

Neste abrigo rochoso, foram identificadas estruturas de combustão, designadas como "fogões", datadas entre $3630 \pm 32$ A. P. (Cal 3980 - 3810 A. P. e $3800-3720$ A. P. - CSIC-2097) e $1315 \pm 28$ A. P. (1290 - 1080 A. P. - CSIC-2094), com tipo de disposição e forma similares, e a presença dos mesmos tipos de vestígios associados (BORGES, 2010). 
Essas fogueiras, além da função culinária verificada, dada a presença de remanescentes ósseos não humanos, foram classificadas como possíveis estruturas crematórias - ou seja, fogueiras utilizadas para a cremação de cadáveres humanos. Isto foi confirmado pela verificação, nos fragmentos ósseos com sinais de queima, coletados sem evidências de alteração, na sua situação estratigráfica (BORGES, 2010).

Além disso, foram observadas em laboratório, indícios de manipulação intencional e marcas de corte na superfície dos remanescentes ósseos humanos, que sugerem a presença de outras práticas funerárias/mortuárias, relacionadas à cremação: o endocanibalismo, ou ingestão ritual de entes falecidos (SILVA, 2018) ${ }^{9}$. Outro fato relevante diz respeito a cronologia definida para as primeiras fogueiras evidenciadas. Registradas em $5 \mathrm{~cm}$ de profundidade, demonstraram que estruturas de combustão em níveis próximos a superfície, nem sempre significam contaminação de marcadores cronológicos, ou vestígios de ocupações contemporâneas, já que foram datadas entre \pm 1300 anos a \pm 1800 anos (BORGES, 2010).

${ }^{9}$ Defendida e aprovada em 2018. 

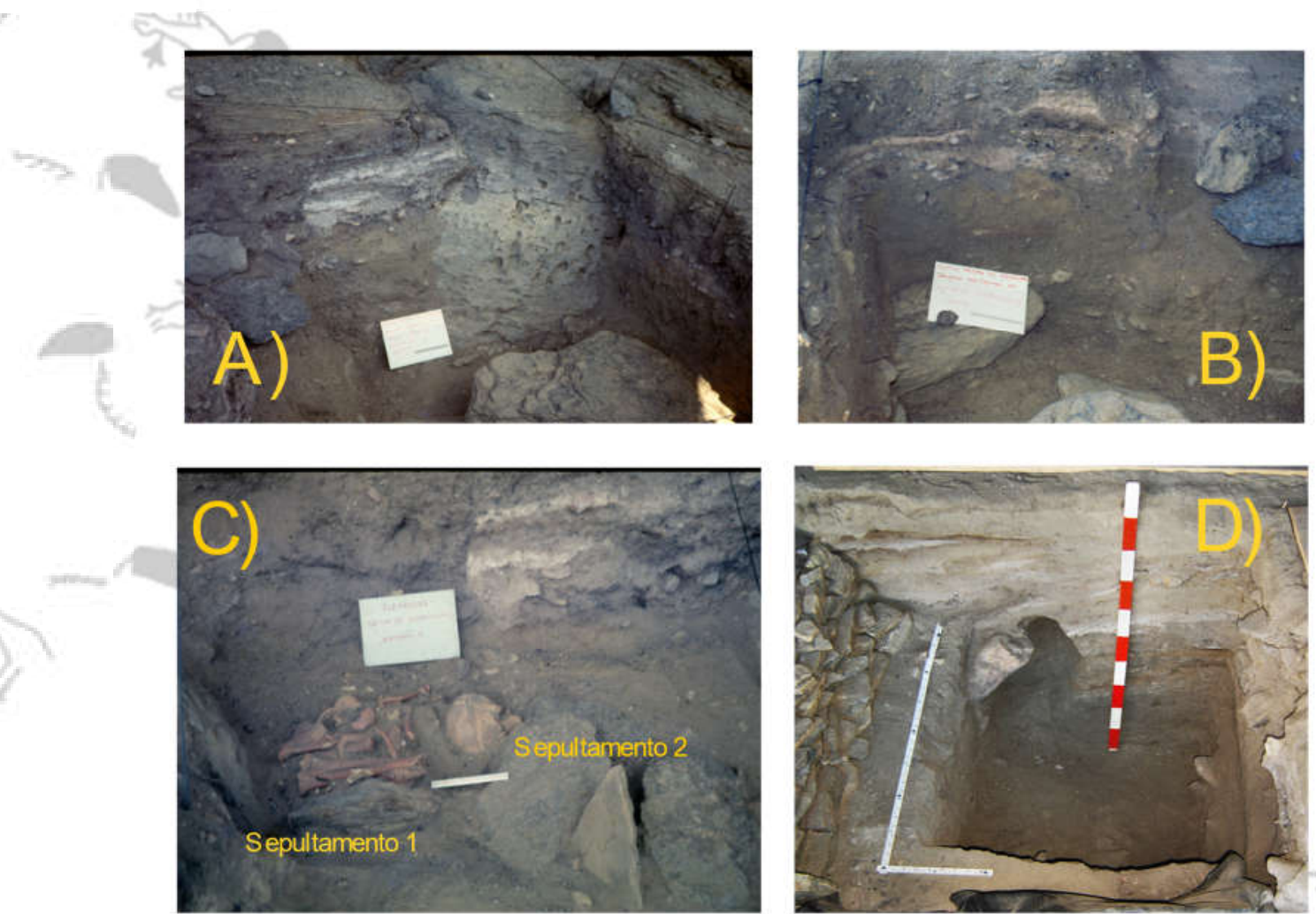

Figura 12 - Estruturas de combustão, compostas por fogueiras sobrepostas, em perfil estratigráfico. A) Setor III; B) Setor IV; C) Sepultamentos 1 e 2, quando de seu registro, no Estrato 2 do Setor III; sítio arqueológico Pedra do Alexandre. D) Estruturas de combustão evidenciadas na quadrícula I3, sítio arqueológico Furna do Umbuzeiro. Carnaúba dos Dantas, RN, Brasil. (Fonte: NEA/UFPE e BORGES, 2010: 165).

Ao se considerar o registro etnohistórico do Seridó potiguar ${ }^{10}$ e a similaridade das estruturas arqueológicas identificadas, mostra-se viável sugerir que, a cremação e o endocanibalismo podem ser representativos, das fases finais das práticas funerárias

${ }^{10}$ BARLEUS, 1980; MOREAU e BARO, 1979; POMPEU SOBRINHO, 1934. 
no sítio arqueológico Pedra do Alexandre. Porém, o tipo de registro dispensado na escavação desses níveis, não coletou dados suficientes, além dos tipos de vestígios coletados e o registro fotográfico ${ }^{11}$, para viabilizar uma análise comparativa entre os assentamentos.

Nas campanhas arqueológicas seguintes, intensificou-se o registro de outras deposições funerárias, o que determinou a caracterização do sítio como espaço cemitério (MARTIN, 1994, 1995-1996, 2008; TORRES, 1995-1996; SANTOS, 1997; SILVA, 2003; CASTRO, 2009; SOLARI et al., 2016(a), 2016(b), SOLARI et al., 2018) (Tabela 03). Após um período sem intervenções arqueológicas, as atividades no sítio foram retomadas em 2010, impulsionadas pela criação do Departamento de Arqueologia da UFPE e a formação de discentes do Curso de Pósgraduação em Arqueologia. Por ainda não terem sido divulgadas de modo efetivo, a XVI campanha e a XVII campanha serão aqui apresentadas em resumo, com destaque aos vestígios mais significativos identificados e os resultados parciais obtidos, em laboratório. Estas campanhas estavam vinculadas ao projeto "Projeto Seridó: Metrologia e Escavação" - INAPAS e foram realizadas em outubro de 2010 e novembro de 2011. Selecionou-se para escavação os setores I, II, III, IV, V, IX, X, XV, XVI, XXVII, XVIII, XXXIV, XXXV, XL, XLI, XLVI, XLVII, LI e LII (Figura 13). As intervenções objetivavam a ampliação e continuidade das áreas

\footnotetext{
${ }^{11}$ Não existem, no banco de dados digital do sítio, desenhos planimétricos, fotos detalhadas das estruturas escavadas, descrição das mesmas e dos vestígios associados, estimativas cronológicas ou outros tipos de informação que permitam análises comparativas objetivas.
} 
anteriormente escavadas (Figura 14), principalmente naqueles setores diretamente atingidos pelo desmoronamento do teto, e a identificação de níveis de ocupação mais antigos, anteriores ou contemporâneos a este evento de colapso parcial do abrigo.

\begin{tabular}{|c|cc|}
\hline $\begin{array}{c}\text { Campanha } \\
\text { arqueológica }\end{array}$ & Início & Finalização \\
\hline I campanha & $01 / 11 / 1990$ & $10 / 11 / 1990$ \\
\hline II campanha & $24 / 11 / 1990$ & $30 / 11 / 1990$ \\
\hline III campanha & $17 / 01 / 1991$ & $25 / 01 / 1991$ \\
\hline IV campanha & $15 / 02 / 1991$ & $27 / 02 / 1991$ \\
\hline V campanha & $13 / 08 / 1991$ & $22 / 08 / 1991$ \\
\hline VI campanha & $09 / 01 / 1992$ & $16 / 01 / 1992$ \\
\hline VII campanha & $06 / 08 / 1992$ & $15 / 08 / 1992$ \\
\hline VIII campanha & $28 / 06 / 1993$ & $07 / 07 / 1993$ \\
\hline IX campanha & $28 / 06 / 1994$ & $08 / 07 / 1994$ \\
\hline X campanha & $02 / 01 / 1995$ & $10 / 01 / 1995$ \\
\hline XI campanha & $17 / 03 / 1995$ & $31 / 03 / 1995$ \\
\hline XII campanha & $23 / 10 / 1995$ & $30 / 10 / 1995$ \\
\hline XIII campanha & $15 / 08 / 1996$ & $30 / 08 / 1996$ \\
\hline XIV campanha12 & Lacuna no banco de & Etiquetas extraviadas: \\
\hline XV campanha & $05 / 12 / 2000$ & 3578 a 3860 \\
\hline XVI campanha & $18 / 10 / 2010$ & $11 / 12 / 2000$ \\
\hline XVII campanha & $01 / 11 / 2011$ & $30 / 10 / 2010$ \\
\hline
\end{tabular}

Tabela 03 - Tabela das Campanhas arqueológicas no sítio Pedra do Alexandre, Carnaúba dos Dantas, RN, Brasil. (Fonte: NEA/UFPE).

\footnotetext{
${ }^{12}$ Observação: O que aqui se denomina de XIV campanha, consiste numa lacuna de quatro (04) anos no acervo digital do sítio, no qual não se sabe quantas expedições foram realizadas, nem que vestígios foram resgatados.
} 


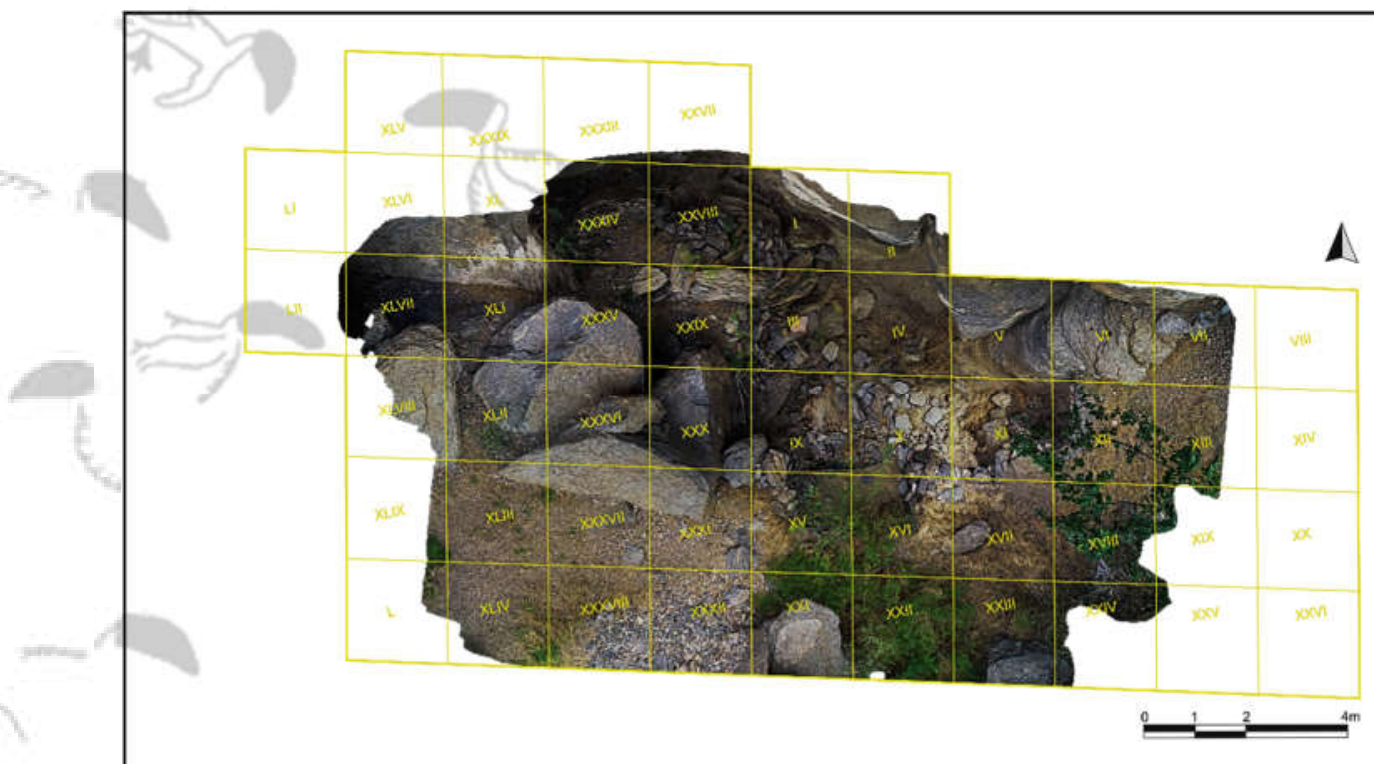

Figura 13 - Planta-baixa em 3D, com malha de setorização sobreposta a imagem. Sítio arqueológico Pedra do Alexandre, Carnaúba dos Dantas, RN, Brasil. (Fonte: Lucas E. S. de Medeiros e Mizael M. S. da Costa, 2020).

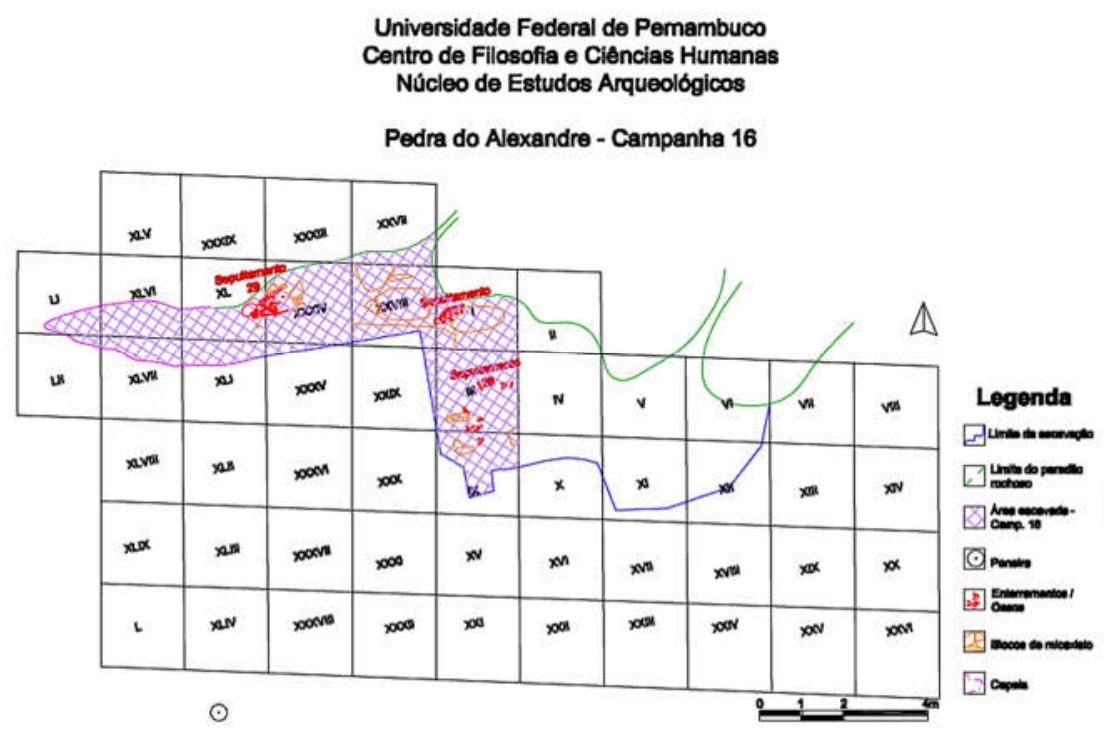

Figura 15 - Plantabaixa do abrigo rochoso, como malha de setorização, $\mathrm{e}$ representação das áreas escavadas na XVI Campanha arqueológica. Sítio arqueológico Pedra do Alexandre, Carnaúba dos Dantas, RN, Brasil. (Fonte: NEA/UFPE). 
Durante as escavações foram evidenciadas estruturas de combustão, onde se coletou, em associação, fragmentos e artefatos líticos, material cerâmico, restos faunísticos e carapaças malacológicas (Figura 15 e Figura 16). Concentradas na porção mais central da área escavada, denominada "área das fogueiras", estas estruturas de combustão indicam a seleção de áreas específicas, para a realização de atividades de subsistência ou vinculadas ao período em que o abrigo era ocupado, durantes a realização dos ritos funerários e práticas gráficas. Foi possível estabelecer uma data para duas destas estruturas de combustão: a mais antiga, no setor III, quadrantes A/D, no oitavo nível do estrato dois (ponto topográfico $\mathrm{n}^{\circ} 908$ ) - 3820 +/- 30 BP (Cal BP 4300 a 4150/ Beta - 327727); e a mais recente, localizada no setor XVI, quadrante A, início do estrato II (ponto topográfico ${ }^{\circ} 539$ ) - 2170 +/- 30 BP (Cal BP 2210 a 2190/ Beta - 327730) (Tabela 02).

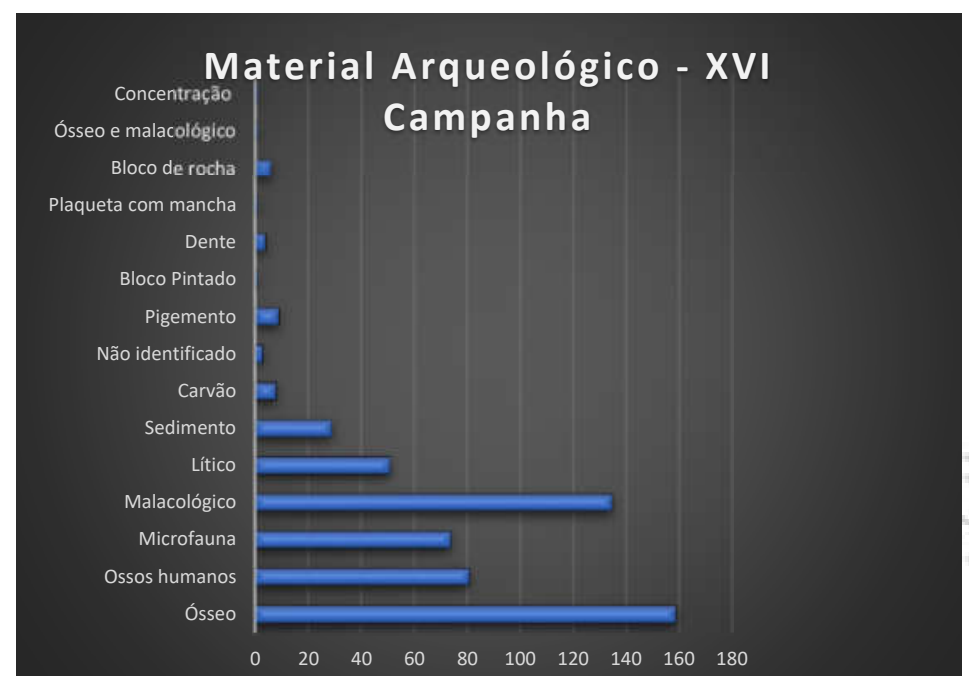

Figura $15-$ Gráfico representando os tipos e a quantidade dos vestígios arqueológicos registrados na XVI Campanha arqueológica realizada no sítio arqueológico Pedra do Alexandre, Carnaúba dos Dantas, RN, Brasil. (Fonte: Banco de dados digitais NEA/UFPE).

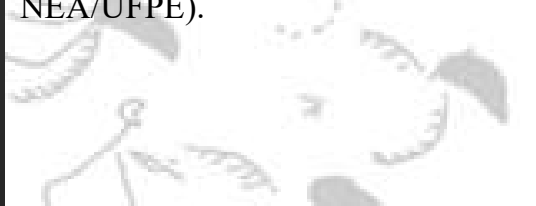




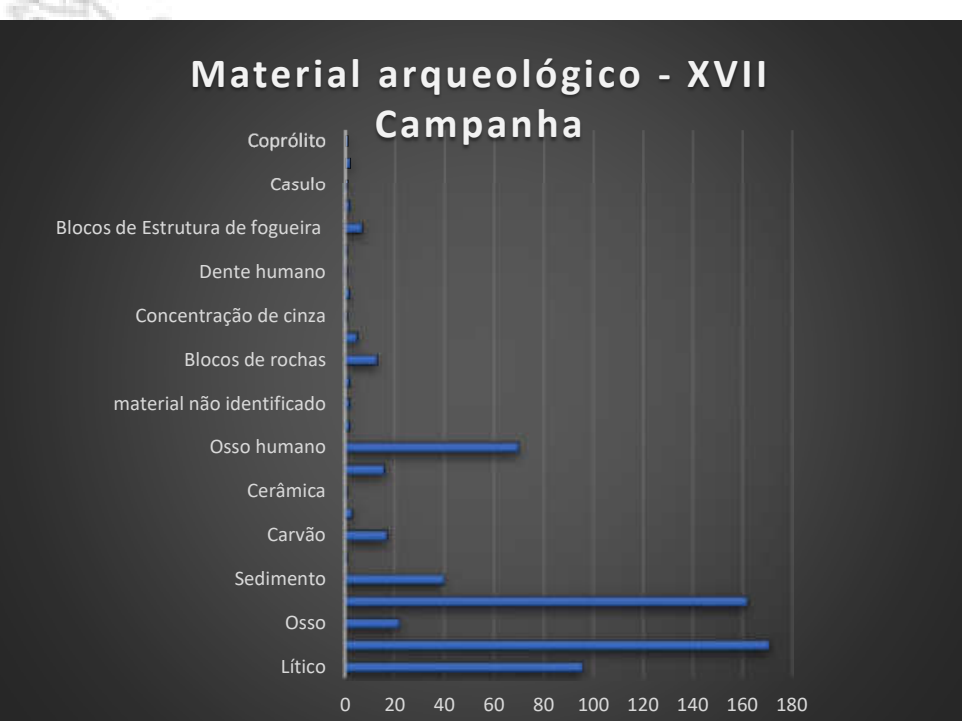

Figura 16 - Gráfico representando os tipos e a quantidade dos vestígios arqueológicos registrados na XVII Campanha arqueológica realizada no sítio arqueológico Pedra do Alexandre, Carnaúba dos Dantas, RN, Brasil. (Fonte: Banco de dados digitais NEA/UFPE).

No setor $\mathrm{X}$, quadrantes $\mathrm{A} / \mathrm{D}$, final do estrato 2, foi evidenciada uma estrutura de blocos líticos endógenos, na qual se verificou marcas de polimento e manchas de pigmento vermelho, associada a trinta e sete (37) fragmentos de óxido de ferros com marcas de uso (polimento). Esta estrutura foi datada em 9140 +/- 50 BP (Cal BP 10480 a 10470/ Beta - 327729) (Figura 17). Em profundidade maior que esta estrutura datada, foi registrado no setor XV, quadrante D, estrato 2, um bloco lítico com mancha de pigmento vermelho. Tomados em conjunto, estes vestígios de práticas gráficas sugerem que estas atividades já eram realizadas, desde as mais antigas ocupações registradas no abrigo (ver Tabela 02 e Tabela 03 ). 

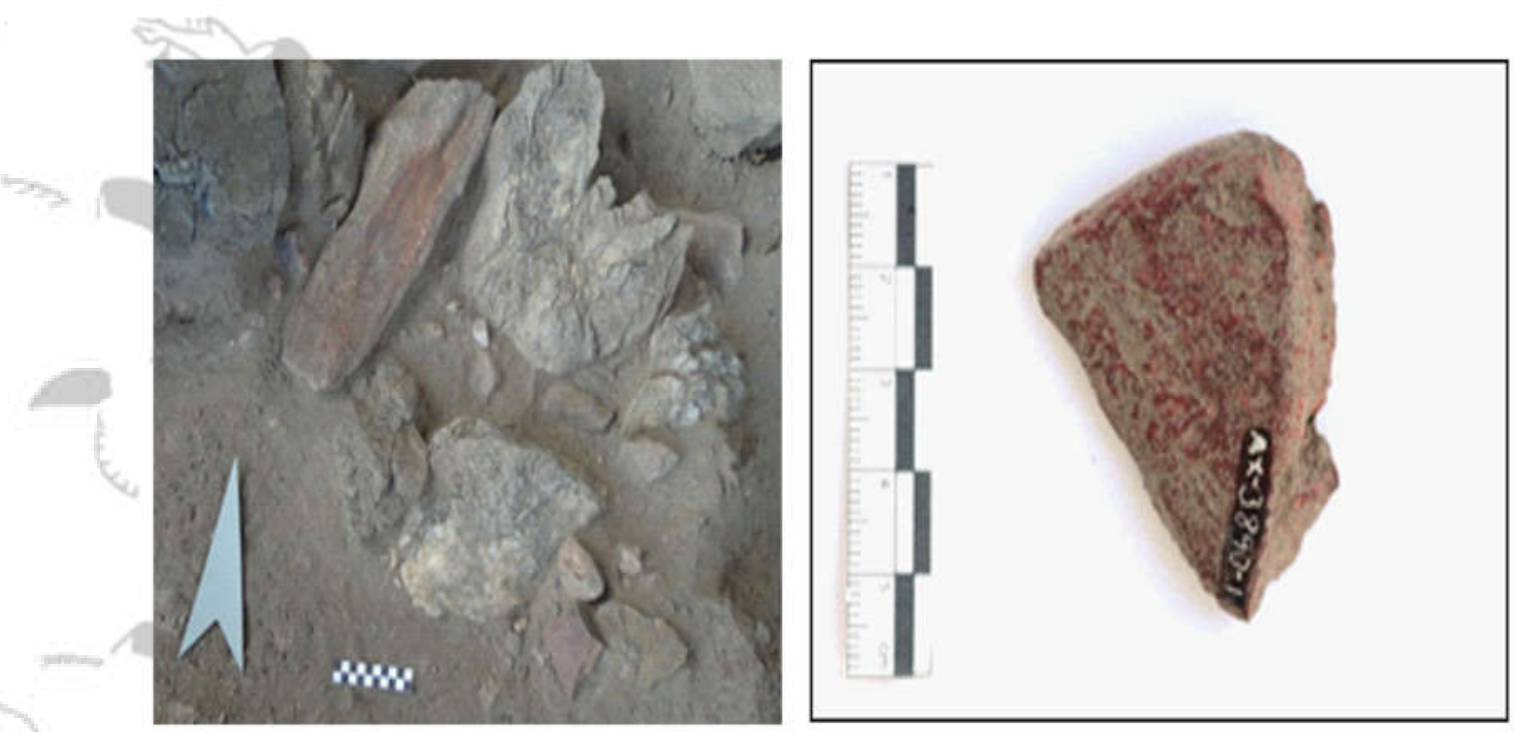

Figura 17 - A) Estrutura com vestígios de práticas gráficas; B) Fragmento de óxido de ferro com marcas de uso. Sítio arqueológico Pedra do Alexandre, Carnaúba dos Dantas, RN, Brasil. (Fonte: Banco de dados digitais - NEA/UFPE).

Durante a XVI campanha arqueológica foram evidenciados: o sepultamento 23 (antigos sepultamentos 20 e 27), o sepultamento 24 (antigo sepultamento 21, atual sepultamento 28) e o sepultamento 25 (antigo sepultamento 22, atual sepultamento 29) (SILVA, et al., 2020). O sepultamento 23 (antigos sepultamentos 20 e 27) consiste em uma deposição primária simples, com esqueleto incompleto de indivíduo adulto feminino, em decúbito lateral direito (Figura 18A). Foi localizado no setor I, quadrante $\mathrm{A}$, nos níveis arqueológicos mais profundos do estrato 2 . Foi datado em 9440 +/- 40 BP (Cal BP 10750 a 10580/ Beta - 327693) (ver Tabela 02). 
O sepultamento 24 (antigo sepultamento 21, atual sepultamento 28) caracteriza-se como um conjunto de fragmentos ósseos humanos disperso entre os setores III e IX; os remanescentes pertencem a vários indivíduos infantis e, pelo menos, um (01) adulto (Figuras 18B, 21 e 22). Os índices de fragmentação, dispersão e conservação indicam possível ação de agentes tafonômicos e pós-deposicionais, de origem hídrica e/ou antrópica. É possível que seja resultado do impacto causado pelo desmoronamento do teto do abrigo, ou de blocos isolados, os quais perturbaram um número maior de estruturas funerárias. Com pelo menos cinco (05) indivíduos representados, este sepultamento não foi datado.

Localizado entre os setores XL e XXXIV, níveis finais do estrato 2, o sepultamento 25 (antigo sepultamento 22, atual sepultamento 29) contêm uma deposição primária simples, de um (01) indivíduo masculino adulto, com a presença de fragmentos ósseos intrusivos de dois indivíduos adultos e um infantil, denominados de Concentração Óssea 1 (CO1) (Figura 18C). O indivíduo principal apresentou sinais de queima nos membros inferiores e na pelve, uma mancha de óxido de ferro sobre costela e associação a um (01) artefato lítico (batedor). Foi datado em 9100 +/- 50 BP (Cal BP 10340 a 10330/ Beta - 327694) (ver Tabela 02).

$\mathrm{Na}$ XVII campanha, foi evidenciado o sepultamento 26 (antigos sepultamentos 30 e 31), localizado no setor X, quadrante A, estrato 3. Em campo, foi registrado como duas estruturas funerárias distintas, mediante a identificação, a curta distância da estrutura principal - um fêmur e uma tíbia articulados e fletidos - de ossos de uma 
mão esquerda articulados e depositados em nicho entre blocos (Figura 18D). Contudo, foi possível verificar em laboratório, que pertenciam ao mesmo indivíduo adulto, possivelmente de sexo feminino (SILVA et al., 2013(a) e 2013(b)). O esqueleto se mostrou incompleto, em sua totalidade e bastante alterado, devido à ação de agentes tafonômicos e pós-deposicionais. Mesmo assim, foi possível determinar uma idade para a estrutura funerária, a partir de marcadores cronológicos coletados na quarta fase de sua exumação: 9170 +/- 40 BP (Cal BP 10430 a10240/ Beta - 327695) (ver Tabela 02).

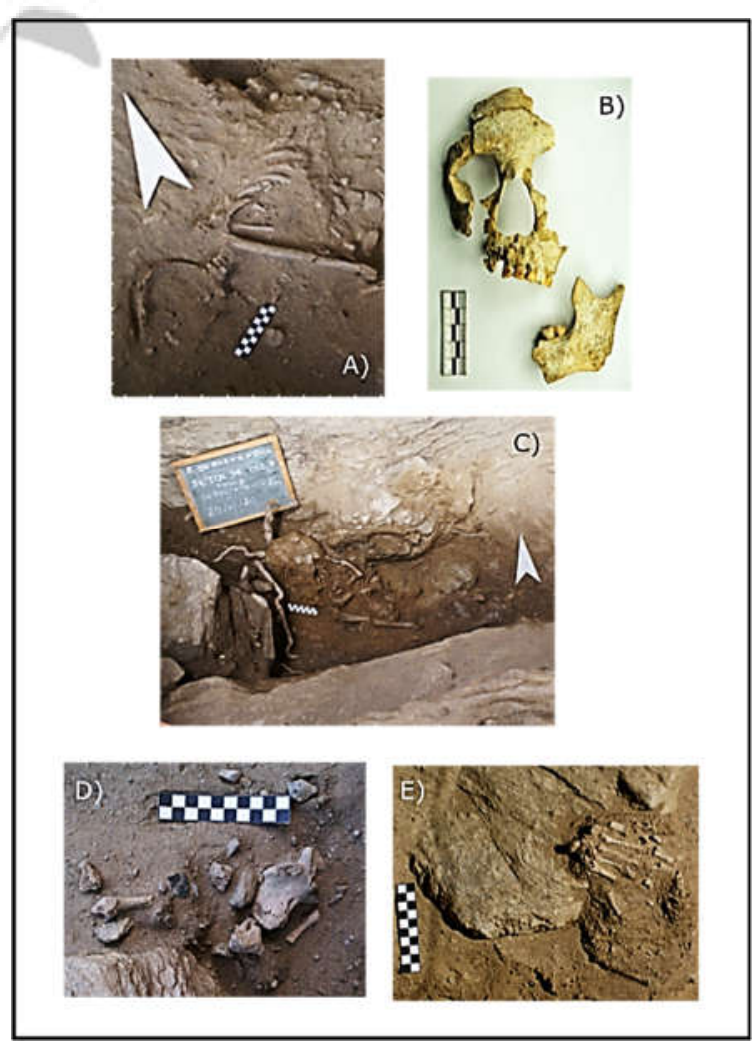

Figura 18 - Sepultamento evidenciados nas XVI e XVII campanhas arqueológicas. A) Sepultamento 23; B) Crânio parcialmente reconstituído do indivíduo principal do sepultamento 24; C) Sepultamento 25; D) Fragmentos ósseos do sepultamento 26; D) Mão esquerda articulada, pertencente ao sepultamento 26. Sítio arqueológico Pedra do Alexandre, Carnaúba dos Dantas RN, Brasil. (Fonte: Banco de dados digitais - NEA/UFPE). 
Diferentemente de outros sepultamentos identificados no sítio, os indivíduos foram inumados em nichos formados por blocos caídos, próximos da parede do abrigo. É possível que covas rasas, recobertas com sedimento e blocos de dimensões menores, tenham sido utilizadas para deposição dos cadáveres. No entanto, a não verificação de indicadores no sedimento, não descarta a possibilidade de uma total ausência de covas funerárias. Quanto a posição dos corpos, foram sepultados em decúbito dorsal e/ou lateral, com membros superiores e inferiores estendidos.

Como característica do conjunto ósseo exumado, não foi possível determinar uma cronologia objetiva para nenhum dos sepultamentos do sítio. A perda de colágeno verificada em amostras enviadas para datação por AMS, demonstraram a impossibilidade de datações diretas, em remanescentes humanos (SULLASI et al., 2018). Nesse sentido, datações relativas foram obtidas a partir de amostras de materiais coletados na matriz circundante aos sepultamentos. Paralelamente, foi possível verificar, em pelo menos quatro (04) amostras ósseas analisadas, processos de permineralização com possível formação de hidroxiapatita secundária, indicando a ação hídrica, nos processos alteradores do registro arqueológico. Isto pode indicar uma antiguidade bem maior do que as datas até então estimadas, para estes restos humanos em processo de fossilização, já que foram localizados na porção do abrigo mais alterada pelo desmoronamento do teto (Silva et al., 2013 (a), 2013(b)).

A degradação de colágenos e outros indicadores importantes para datações radiocarbônicas por AMS - ou mesmo análises de DNA - minimizam o potencial 
analítico e interpretativo de determinados tipos de vestígios arqueológicos recuperados. Da mesma maneira, as remodelações sofridas pela matriz sedimentar, mediante o desmoronamento parcial do abrigo, a quedas de bloco, a ação das águas e as ações antrópicas antigas perturbaram a deposição original de várias estruturas funerárias, dificultando a identificação de tipos de inumação e a definição objetiva das práticas funerárias realizadas em determinados sepultamentos (SILVA et al., 2020).

Entretanto, é possível demonstrar a confiabilidade da cronoestratigrafia definida, já que as datas obtidas não apresentaram anomalias estratigráficas, que configurassem perturbação intensa dos níveis arqueológicos escavados (ver Tabela 01). Localizados na porção central do abrigo, o pacote sedimentar, que continha as estruturas funerárias exumadas antes do ano de 2010, foi aquele que apresentou o menor índice de alterações deposicionais, decorrentes do colapso do teto do abrigo e queda de blocos (MUTZEMBERG, 2007). Destes, apenas o sepultamento 3 destoa da situação deposicional: localizado em conta altimétrica superior e mais próxima da superfície. Diferente dos sepultamentos datados no mesmo período, sua posição estratigráfica pode ser um indicativo da topografia do espaço interno do abrigo, anterior ao evento de colapso.

Nesse sentido, pode-se sugerir que, no período anterior ao colapso parcial do abrigo, havia certa liberdade na escolha dos espaços para realização de rituais funerários e a inumação dos corpos, dada a maior amplitude do espaço ocupacional. Além disso, 
permite vislumbrar uma complexa topografia para esta área interna, onde a matriz sedimentar do estrato I, depositou-se sobre blocos caídos e acomodados na rocha matriz, preenchendo nichos e espaços vazios. Este processo de pedogênese pode ser datado na transição Pleistoceno/Holoceno, assim como, no início do período holocênico (MUTZEMBERG, 2007).

Isto se fortalece com as datas determinadas nas últimas campanhas realizadas no abrigo: XVI e XVII campanhas arqueológicas (2010/2011). A área selecionada para realização de intervenções arqueológicas, já havia sido escavada em etapas anteriores e, por esse motivo, os sedimentos retirados e as estruturas arqueológicas identificadas, estavam relacionados aos níveis de ocupação mais antigos. Localizados em maior profundidade, estes níveis arqueológicos e estruturas funerárias apresentaram o menor índice de alteração decorrente do colapso parcial do teto, sugerindo que as inumações foram realizadas em períodos anteriores ou contemporâneos ao evento de colapso parcial. Esta verificação permitiu estimar uma cronologia para a queda e a deposição destes blocos, assim como explicar a situação estratigráfica e os agentes pós-deposicionais que agiram sobre as estruturas funerárias e outros vestígios arqueológicos (ver Tabela 02 e Tabela 03).

Localizado no intervalo temporal entre \pm 10000 anos $\mathrm{e} \pm 8000$ anos, este evento foi condicionante para as ocupações subsequentes do sítio, determinando uma redução do espaço funerário e, possivelmente, uma redução no espaço utilizado nas atividades gráficas (Figura 19). Este fato pode ser verificado pela mudança nos 
tipos de inumação, datadas após \pm 9000 anos. Neste período, verifica-se o um incremento no número e nas formas de inumações secundárias, simples ou coletivas, desde as datas mais antigas deste período, até o desaparecimento das inumações no registro arqueológico, há \pm 2600 anos atrás. Além disso, inumações primárias, simples e/ou coletivas, apresentaram outras características, principalmente no que diz respeito a posição dos corpos. Depositados com membros superiores e inferiores fletidos, às vezes em posições intensamente flexionadas, contidas na cova pela sobreposição de blocos líticos (endógenos ou exógenos), indica a redução das dimensões das covas utilizadas para o sepultamento e, possivelmente, dos espaços disponíveis para sua realização.

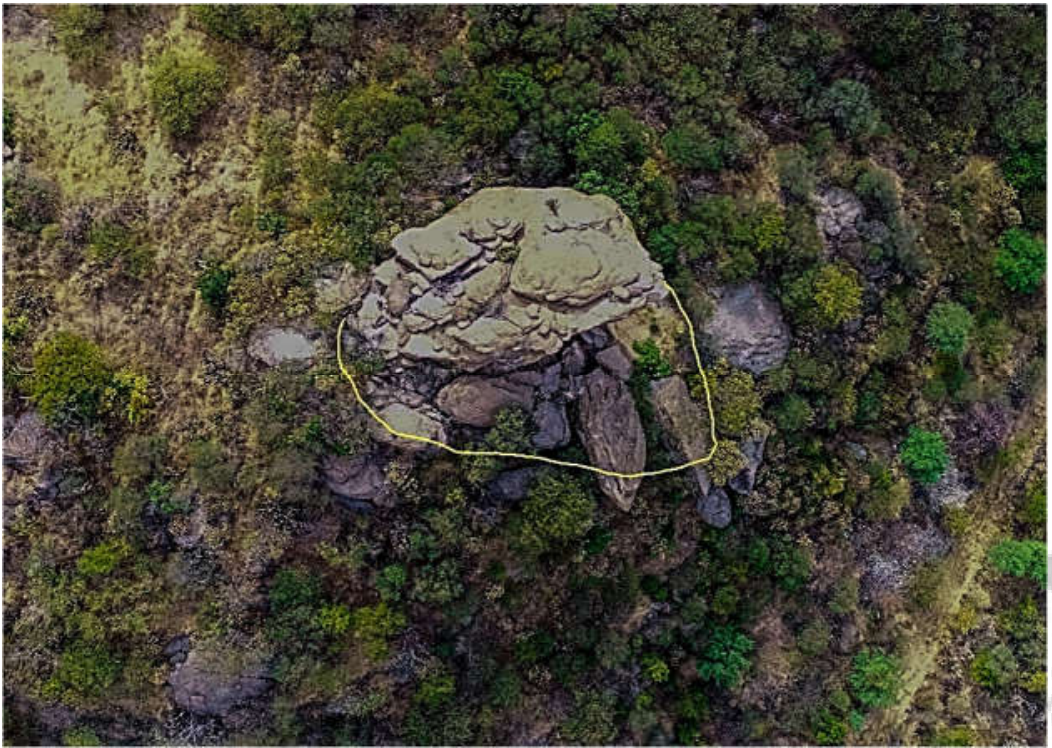

Figura 19

Reconstituição hipotética, a partir de foto aérea, da forma do teto do abrigo, antes de seu colapso parcial. Sítio arqueológico Pedra do Alexandre, Carnaúba dos Dantas, RN, Brasil. (Fonte: Lucas E. S. de Medeiros, 2020. Elaboração: Fabio Mafra, 2020). 
Verificadas estas novas evidências, foi possível sugerir uma periodização hipotética para as práticas mortuárias verificadas no sítio Pedra do Alexandre. Nesse sentido, identificou-se três (03) momentos distintos, que podem ter sido impulsionados pelo evento de colapso parcial do abrigo. O primeiro período, datado entre \pm 10800 AP e \pm 9000 AP, caracteriza-se pela deposição em covas rasas, preenchidas de blocos líticos, ou mesmo sem a abertura de covas, em nichos entre blocos caídos, em inumações primárias simples, com os membros superiores e inferiores, distendidos ao longo do corpo. É possível, que estas ocupações tenham ocorrido em períodos anteriores ao desmoronamento do teto.

Posteriormente, a partir de $\pm 8500 \mathrm{AP}$, os grupos humanos que utilizavam o abrigo, viram-se forçados a ocupar uma área mais restrita e otimizar seu uso, mediante a redução dos espaços delimitados para abertura de covas e deposição dos cadáveres. Logo, as estruturas funerárias se configuraram em deposições primárias, simples ou coletivas, e deposições secundárias, da mesma maneira simples ou coletivas, indicando o surgimento de práticas funerárias com tipologias distintas do período anterior (Figura 20). 


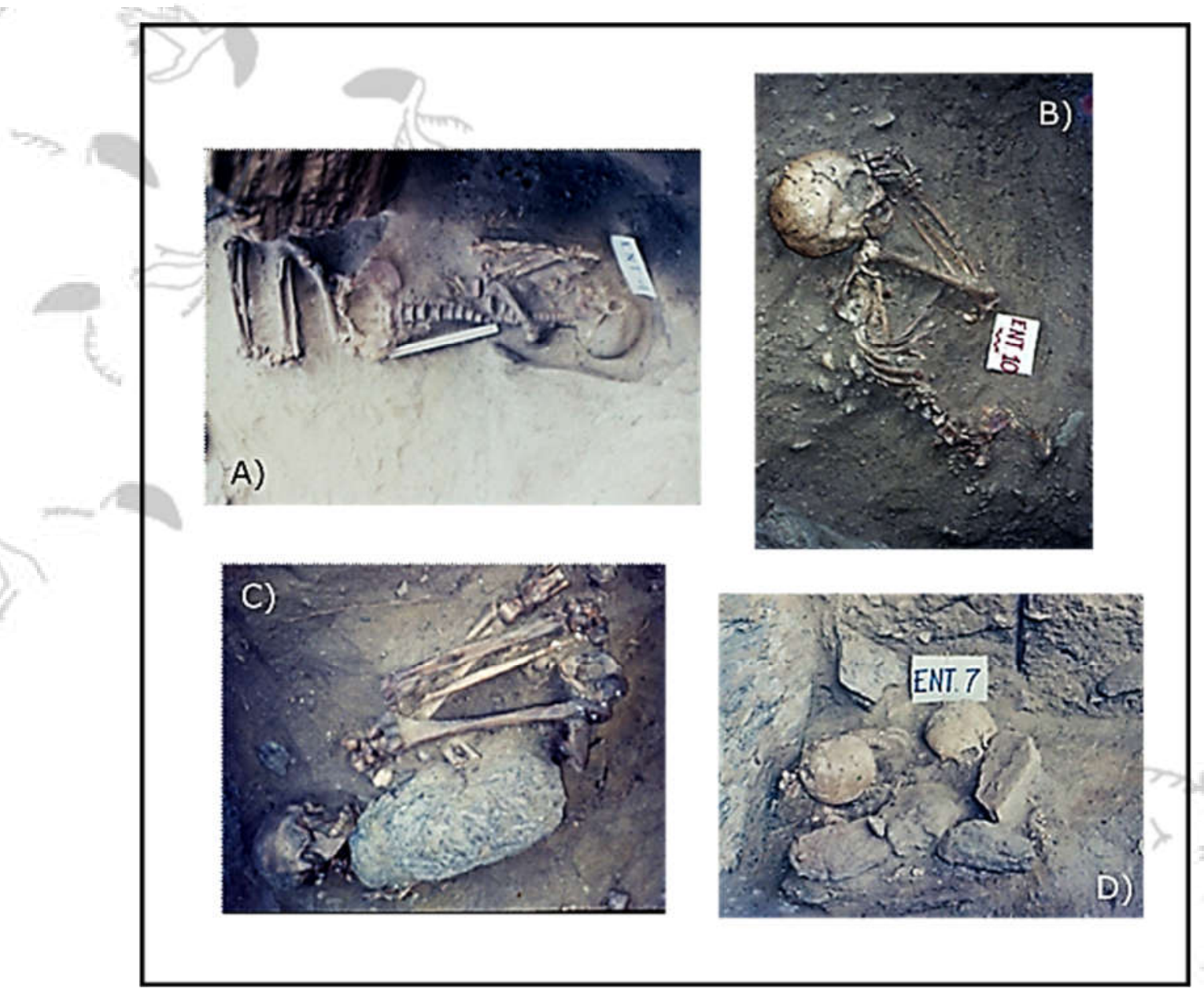

Figura 20 - Sepultamentos primários demonstrando a variação temporal, dos índices de flexão corporal nas inumações. A) Sepultamento 4: $8280 \pm 30$ anos AP; B) Sepultamento 10: sem datação; C) Sepultamento 2: $4160 \pm 70$ anos AP; Sepultamento 7: $2620 \pm 60$ anos AP. Sítio arqueológico Pedra do Alexandre, Carnaúba dos Dantas RN, Brasil. (Fonte: Banco de dados digitais NEA/UFPE).

O momento final, datado em \pm 2500 AP, consiste no abandono das inumações sem, contudo, significar o abandono do sítio, ou mesmo de sua função funerária. Como 
acima mencionado, as relações de identidade entre as estruturas de combustão, evidenciadas sobre as estruturas funerárias nas primeiras campanhas arqueológicas, e os "fogões" escavados no sítio Furna do Umbuzeiro, sugerem outros tipos de tratamento mortuário, que envolveriam o descarne, a cremação e, possivelmente, o consumo ritualístico de cadáveres (endocanibalismo).

Durante a escavação da quarta decapagem dos setores III e IX, realizada na XVI campanha arqueológica do Pedra do Alexandre, evidenciou-se uma lente de argila, associada a uma estrutura de combustão e alguns fragmentos ósseos que, na decapagem seguinte seriam relacionados ao sepultamento 24 (Figura 21 e Figura 22). No seu registro, foi interpretada como uma das causas para explicar a situação estratigráfica do conjunto ósseo associado. Ou seja, o índice de dispersão e fragmentação verificado no sepultamento 24 , condicionou sua classificação como uma estrutura tafonômica composta por fragmentos ósseos de várias estruturas funerárias, perturbadas por ação hídrica (SILVA et al., 2013(a) e 2013 (b)). 


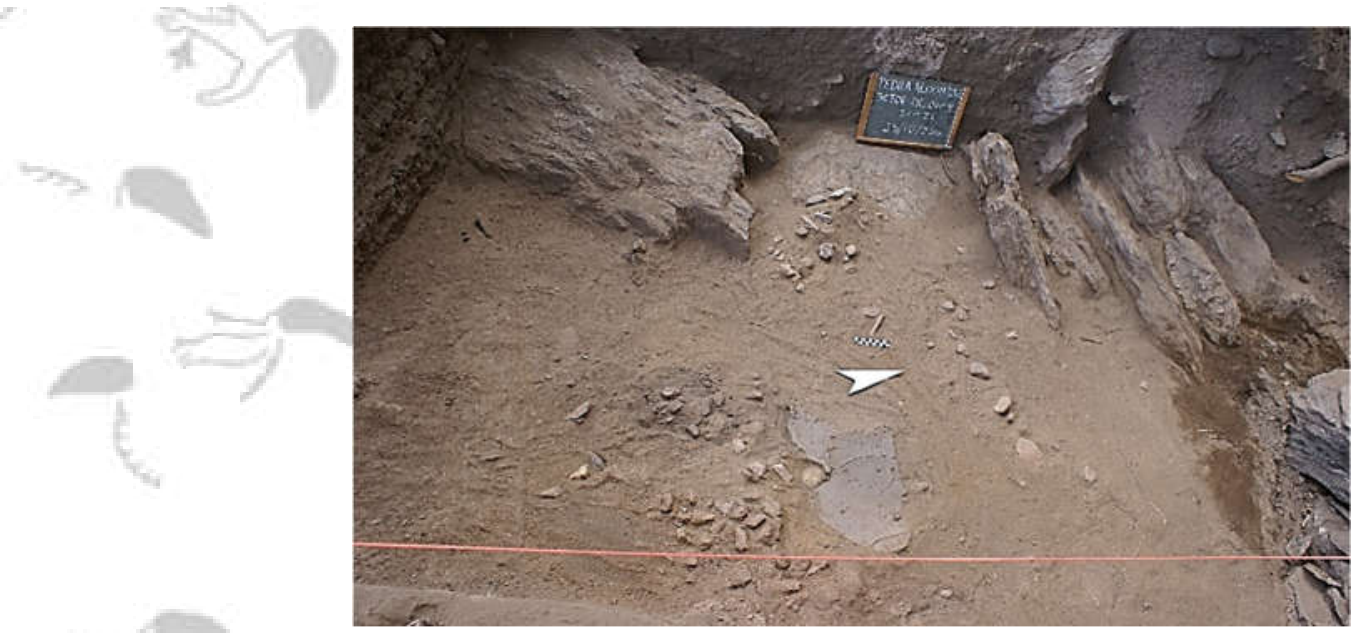

Figura 21 - Vista geral dos setores III e IV, onde se vê lâmina de argila associada a estrutura de combustão e aos remanescentes ósseos humanos do Sepultamento 24. Sítio arqueológico Pedra do Alexandre, Carnaúba dos Dantas, RN, Brasil. (Fonte: NEA/UFPE).

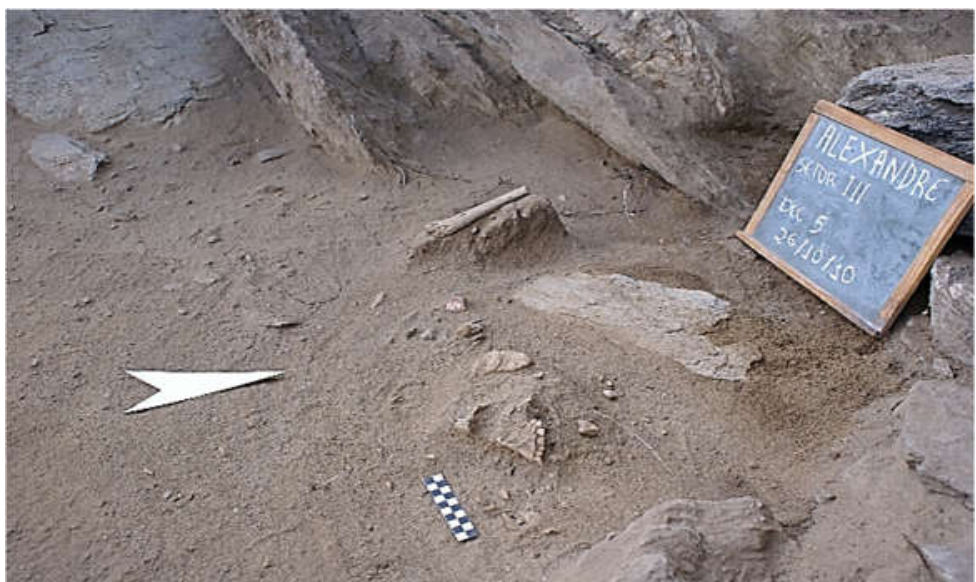

Figura 22 - Detalhe do Sepultamento 24. Sítio arqueológico Pedra do Alexandre, Carnaúba dos Dantas, RN, Brasil. (Fonte: NEA/UFPE). 
Ao se observar o registro fotográfico do nível arqueológico e do perfil estratigráfico revelados nos setores III e IX, nota-se em associação com a lente de argila mencionada, além dos fragmentos ósseos do sepultamento 24 , outros vestígios que não permitem uma verificação objetiva de processos pós-deposicionais perturbando a matriz sedimentar. O primeiro a se destacar, é uma estrutura de combustão, identificada pela alteração térmica do sedimento e a disposição espacial dos fragmentos rochosos que a delimitavam. A lente de argila encontra-se depositada sobre esta estrutura de combustão, a qual não parece ter sido perturbada pela intrusão do material exógeno (Figura 23). Outro, diz respeito a estrutura de combustão visível no perfil oeste do setor III, que apresentou uma espessa lente de cinzas, compondo sua forma e contorno (Figura 24). Um evento natural que permitisse a formação de uma lente de argila com essas características, não teria também alterado a disposição original dessas estruturas?

Infelizmente, não há nenhuma discussão ou interpretação sobre esta situação estratigráfica, além dos relatórios de bioarqueologia e antropologia forense, que descrevem e interpretam as estruturas funerárias, exumadas entre 2010 e 2011. Além do registro fotográfico, gráfico, topográfico e fílmico, no banco de dados digital do assentamento, não há um relatório detalhado das intervenções arqueológicas, nem tampouco, cadernos de campo que permitam o resgate de detalhes mais objetivos, para a compreensão dos processos pedogenéticos deste material exógeno. Por esse motivo, não pode ser descartada uma origem antrópica para deposição da lente de argila verificada. 

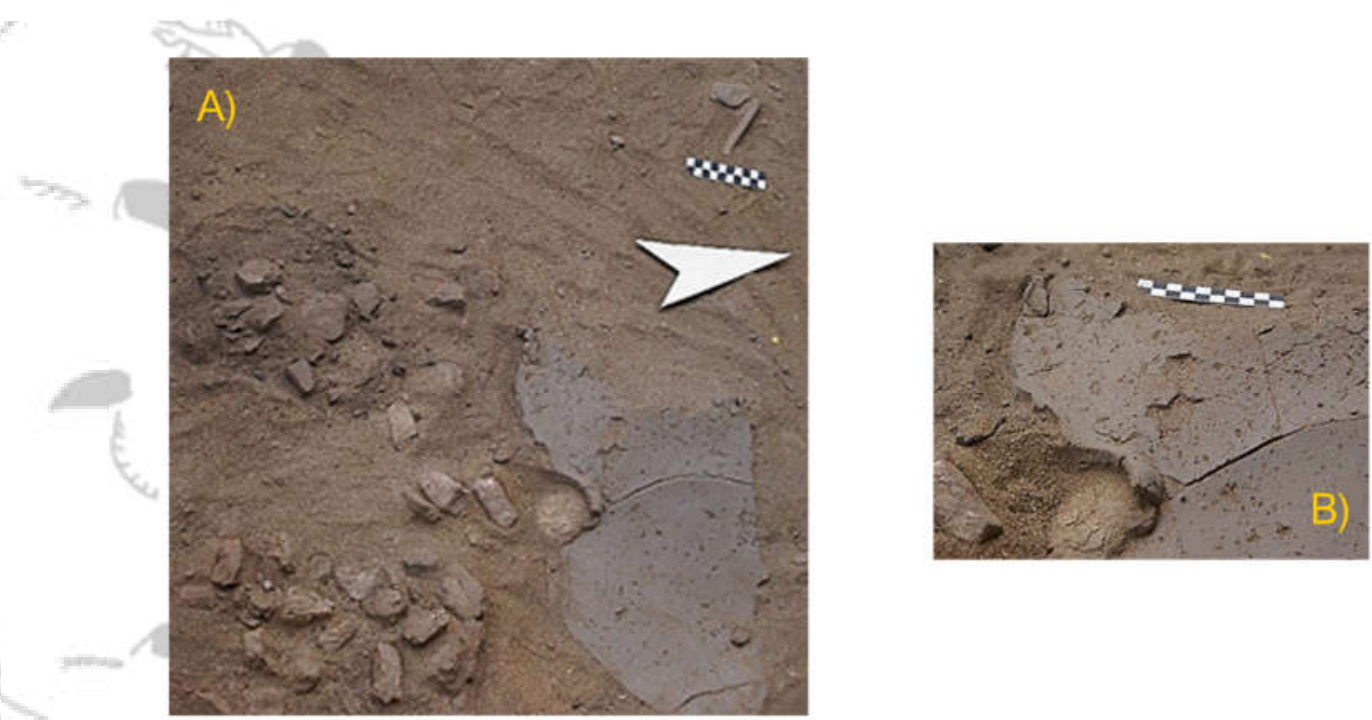

Figura 23 - A) Lente de argila depositada sobre estrutura de combustão. B) Detalhe: acomodação da lente de argila sobre fragmento lítico da estrutura de combustão. Sítio arqueológico Pedra do Alexandre, Carnaúba dos Dantas, RN, Brasil. (Fonte: NEA/UFPE).

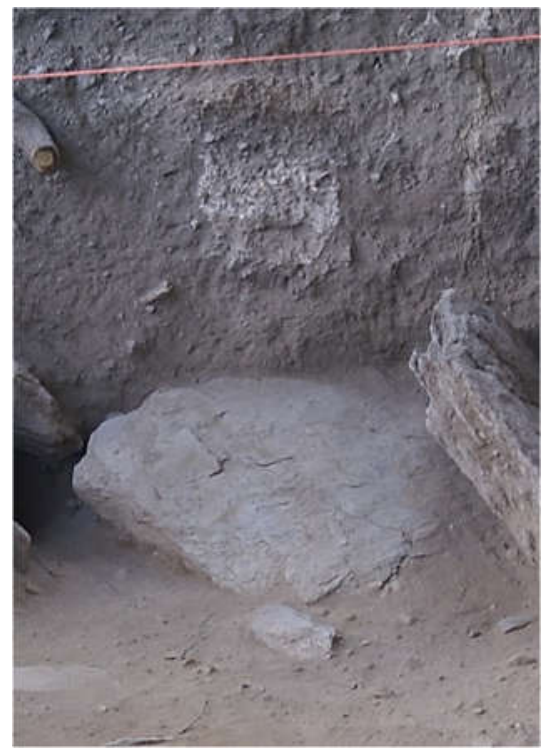

Figura 24 - Lente de cinzas de estrutura de combustão evidenciada no Setor III. Sítio arqueológico Pedra do Alexandre, Carnaúba dos Dantas, RN, Brasil. (Fonte: NEA/UFPE). 
Acerca da adoção e do desenvolvimento da tecnologia ceramista, foi possível propor uma estimativa cronológica para sua introdução no assentamento. Nesse sentido, foram utilizadas três (03) datações radio carbônicas definidas para o sepultamento $09-2890 \pm 25$ anos AP (CSIC-966), 2860 \pm 25 anos AP (CSIC-945), $2750 \pm 40$ anos AP (CSIC-1053) - e a datação radio carbônica estabelecida para o sepultamento 07 - 2620 \pm 60 anos AP (CSIC-1061). Isto permitiu determinar um intervalo cronológico de $2890 \pm 25$ anos AP a $2620 \pm 60$ anos AP, para o vasilhame cerâmico coletado, o que coincidiu com as datas verificadas nos sítios litocerâmicos a céu aberto, da área arqueológica do Seridó - \pm 2800 anos AP e \pm 2700 AP (NOGUEIRA, 2017) - e no material cerâmico do sítio Furna do Umbuzeiro \pm 2600 anos AP (BORGES, 2010).

Este conjunto vestigial já havia sido alvo de análises tecno-tipológicas, anteriormente (FONTES, 2003). Contudo, a abordagem metodológica anteriormente utilizada, dificultou a análise comparativa pretendida, com os perfis técnicos definidos em outros assentamentos da região. Por este motivo, optou-se pela revisão dos dados, com a adição dos novos fragmentos, coletados nas últimas campanhas, além da definição de um perfil técnico cerâmico mais objetivo ${ }^{13}$.

13 Esta revisão analítica foi realizada pela arqueóloga Claúdia Oliveira, nas dependências laboratoriais do Departamento de Arqueologia da UFPE. 
Quando se observa os resultados desta análise, à luz dos dados obtidos em assentamento a céu aberto recentemente analisados, é possível perceber similaridades que permitem estabelecer relações de identidade entre os conjuntos cerâmicos identificados na área arqueológica do Seridó. Além do Pedra do Alexandre, a tecnologia ceramista foi registrada em vários assentamentos, no decorrer dos últimos dez (10) anos de pesquisa (BORGES, 2010; NOGUEIRA, 2017). Estes sítios, caracterizados como ocupações lito-cerâmicas a céu aberto, têm sido interpretados como acampamentos temporários - sítios habitacionais e logísticos - que podem estar culturalmente relacionados àqueles onde se desenvolveram práticas pictóricas e funerárias, as quais predominam nos enclaves pré-históricos da região. Dentre eles, podemos citar: Baixa do Umbuzeiro, Baixa do Umbuzeiro II, Alto dos Marcolinos, Pereira I, Meggers I e Meggers III. Para estes, foi possível estabelecer perfis técnicos cerâmicos, que sugerem um horizonte cultural comum (NOGUEIRA, 2017), que compartilham escolhas técnicas com o material cerâmico do Pedra do Alexandre (OLIVEIRA, com. pess.).

No que concerne aos dados cronológicos, estes assentamentos foram datados, a partir de fragmentos cerâmicos coletados em estratigrafia e associados a estruturas de combustão, em 2840 \pm 30 anos AP (Cal AP 3000 a 2850/ Beta-330557) e 1300 \pm 30 anos AP (Cal AP 1290 a 1180/ Beta-330556) (NOGUEIRA, 2017). Outro sítio arqueológico, neste caso em abrigo rochoso, o qual também permitiu a definição cronológica de vestígios cerâmicos, foi o Furna do Umbuzeiro. Neste, uma estrutura de combustão datada em $2666 \pm 30$ anos AP (Cal AP 2800 - 2700 (90,1\%) / CSIC- 
2098), apresentou um (01) fragmento cerâmico depositado sobre suas cinzas (BORGES, 2010). Tais datas permitiram verificar, que a cronologia relativa aqui proposta para o material cerâmico do Pedra do Alexandre, não se distancia daquelas definidas para situações estratigráficas mais controladas. Nesse sentido, pode-se afirmar que a introdução da tecnologia ceramista, na área arqueológica do Seridó, deu-se há pelo menos, \pm 3000 anos AP.

Nesse sentido, quando confrontados com os dados obtidos para o material cerâmico do sítio Pedra do Alexandre, observa-se que os sítios acima citados apresentam similaridades que sugerem um perfil técnico cerâmico compartilhado entre os sítios lito-cerâmicos a céu aberto e os sítios em abrigos rochosos. As diferenças verificadas entre os conjuntos cerâmicos de cada sítio, configuraram-se mais como variações quantitativas, que não influenciaram a classificação qualitativa e funcional do vasilhame. Ou seja, antes de variações culturais, estas podem estar relacionadas aos tipos de atividades desenvolvidas, em cada um desses assentamentos.

Quanto à classificação deste horizonte cultural, os dados ainda se mostram frágeis, mesmo com relações de identidade com a Tradição Pedra do Caboclo, subtradição Papeba, anteriormente sugeridas (BORGES, 2010). Por outro lado, não é possível descartar, mediante os dados obtidos, a hipótese de uma origem autóctone, para este tipo de tecnologia. De toda forma, a adoção de objetos cerâmicos pelas populações caçadoras-coletoras do Seridó potiguar, deve ter se dado por intrusão de traços 
culturais, a partir da dispersão tecnológica entre grupos étnicos diferentes, o que não significou contatos populacionais efetivos, durante esse processo (BROCHADO, 1984).

\section{CONSIDERAÇÕES FINAIS}

Quando se estuda as práticas funerárias em populações pré-históricas, o vestígio mais importante consiste nos remanescentes ósseos humanos, propriamente ditos, e sua relação com os objetos depositados, em associação aos restos mortais. Além do valor heurístico para abordagens forenses e bioarqueológicas, tais vestígios permitem acessar outras dimensões de significados, que extrapolam a materialidade do registro arqueológico (BINFORD, 1971; BIRD, 1988; SOUZA e RODRIGUESCARVALHO, 2013). A forma de deposição dos cadáveres, os acompanhamentos funerários associados e as atividades vinculadas aos ritos funerários funcionavam como marcadores identitários, não somente para a coletividade praticante, mas também para o indivíduo sepultado (STRAUSS, 2010).

Nesse sentido, as estruturas funerárias em um sítio arqueológico são aspectos materiais, são reminiscências de ritos de passagem, que garantiram o desenvolvimento de novas identidades para os mortos, com a transição de seus corpos e personas sociais, em ossos e outros tipos de entidades (SANTOS, 2009; SAXE, 1977). Dito de outra maneira, o tratamento dispensado ao falecido reflete aspectos sociais, materializados em gestos e procedimentos ritualizados, 
consensuais e coletivos, os quais são compartilhados em um horizonte cultural, por longos intervalos temporais (CHAPMAN, 2003).

Em grupos caçadores-coletores sul-americanos, foi verificada uma intensa variação temporal, regional, cultural e tipológica, das práticas mortuárias e funerárias (STRAUSS, 2010). Estas podem ser distribuídas em três (03) categorias de inumação: (a) inumações primárias, (b) inumações secundárias e (c) a cremação (BIRD, 1988). Os espaços selecionados para a deposição dos mortos, na maioria das vezes, consistiam no próprio espaço doméstico, onde as três (03) categorias supracitadas, em muitas ocasiões, coexistiam no mesmo intervalo temporal e vinculadas a um horizonte cultural comum (SANTORO et al., 2005). Esta situação, na qual não se verifica uma formalização de espaços exclusivos para a realização de ritos funerários, é geralmente descrita, na bibliografia especializada, como cemitérios, ou espaços cemiteriais (PETTITT, 2011).

A denominação, desenvolvida para classificar espaços funerários em populações agrícolas e com reduzida mobilidade espacial, agrega um caráter anacrônico e, culturalmente, não adequado para a interpretação das práticas mortuárias em caçadores-coletores. Nesse sentido, o uso de conceitos como "pontos notáveis" (landmarks) na paisagem e lugares com a persistência temporal de deposições funerárias ("persistent places" - LITTLETON e ALLEN, 2007) permitem uma definição mais objetiva para as práticas funerárias de grupos culturais caracterizados por uma mobilidade espacial mais dinâmica (STRAUSS, 2010). 
A formação de "lugares persistentes" se dá mediante três motivos: (a) a existência de qualidades atraentes para a realização de determinadas atividades, (b) a presença de estruturas ou vestígios arqueológicos, que motivem a reocupação deste mesmo espaço - ex.: grafismos rupestres - (c) e/ou processos de longa duração de reocupações recorrentes e sucessivas (SCHLANGER, 1992).

Os resultados obtidos no sítio Pedra do Alexandre, inserem o abrigo no cerne destas discussões teóricas sobre grupos caçadores-coletores e suas tradições funerárias. A presença de áreas de ocorrência de estruturas de combustão, não associadas a estruturas funerárias - "Garrincho II" -, indica momentos em que o assentamento foi utilizado como acampamento temporário, para a realização de atividades de subsistência, ainda não definidas. Além disso, (a) o número reduzido de indivíduos sepultados, no longo período de ocupação do abrigo - \pm 10500 anos a 2600 anos AP - (MARTIN, 2008; SOLARI et al., 2016(a) e 2016(b)); (b) as lacunas temporais verificadas na cronoestratigrafia definida, durante o Holoceno Médio (MUTZENBERG, 2007); (c) o registro de sítios com apenas uma deposição funerária, na mesma região e intervalo cronológico - sítio Mirador do Boqueirão e sítio Pedra do Chinelo, ambos em Parelhas-RN (MARTIN, 2008; VIDAL, 2002); e (d) a não exclusividade funcional no abrigo - acampamento temporário, atividades de subsistência, atividades lúdicas, práticas gráficas, práticas funerárias - podem sugerir um oportunismo, na seleção de espaços para deposição dos mortos. 
Entretanto, o próprio assentamento atesta uma recorrência temporal do uso funerário, que contradiz a relação determinista entre mobilidade espacial e formalização de espaços cemiteriais. Da mesma forma, o registro arqueológico sulamericano apresenta diversos casos de populações caçadoras-coletoras que selecionaram locais específicos, geralmente "pontos notáveis" na paisagem marcos territoriais -, para a deposição de seus mortos (STRAUSS, 2010). Contudo, o contexto cultural em questão, não viabiliza o uso do conceito e a classificação de assentamentos deste tipo como cemitérios. A especificidade funcional que o termo denota, tende a direcionar os métodos de intervenção arqueológica e as análises laboratoriais decorrentes, para o estudo e classificação das estruturas funerárias, em detrimentos de outros vestígios e estruturas identificadas. Deste modo, o registro de ocupações temporárias, associadas ou não às práticas funerárias, e a recorrência temporal desta função permitem classificar o sítio Pedra do Alexandre como "ponto notável" (landmark) e "lugar persistente" (persistent place), preferencialmente selecionado para a realização de depósitos funerários - já que até o momento não foi identificado outro assentamento, com número significativo de indivíduos inumados, na área arqueológica do Seridó (MARTIN, 2008).

As deposições funerárias registradas, apresentaram o mesmo tipo de diversidade tipológica verificada em outros assentamentos caçadores-coletores sul-americanos. Estão representadas inumações primárias e secundárias, com ou sem acompanhamentos funerários, além de concentrações ósseas com deposição alterada por processos pós-deposicionais, de origem natural e/ou antrópica (SILVA 
et al., 2013(a) e 2013(b)). A ocorrência de estruturas de combustão, depositadas sobre os sepultamentos mais próximos da superfície, e formadas por fogueiras sobrepostas em espaço delimitado, sugerem o registro de práticas crematórias. A coleta de fragmentos ósseos humanos, no interior destas estruturas de combustão e associadas a ossos não humanos, juntamente com a verificação de marcas de corte e manipulação intencional, (SILVA et al., 2013(a) e 2013(b)), indicam procedimentos de descarne e, possivelmente, a ingestão ritualizada de partes ou de todo corpo humano. Ou seja, sugere-se a possibilidade de registro de rituais funerários endocanibais, no assentamento.

O número atual de deposições funerárias é de vinte e quatro (24) sepultamentos simples e coletivos, com $\mathrm{NMI}=48$, distribuídos entre indivíduos masculinos e femininos. Quanto a faixa etária estimada, verificou-se a presença de adultos (NMI $=23)$ e subadultos $(\mathrm{NMI}=25)$. O maior número de indivíduos infantis, depositados no mesmo espaço e com tratamentos cadavéricos similares aos indivíduos adultos (secundarização, uso de pigmento e cremação), entra em choque com o modelo teórico de persona social; no qual, somente indivíduos com vida social ativa, demandaria um maior investimento nos ritos funerários (SAXE, 1970). Isto demonstra, além do alto índice de mortalidade infantil, decorrente de patologias invisíveis no registro ósseo (SOLARI et al., 2018), uma importância simbólica da infância, pelo menos no que diz respeito à sobrevivência grupal, entre estas populações. Tal interpretação se fortalece, quando observados alguns grafismos emblemáticos da Tradição Nordeste, que na região está representada, entre outras, 
pela Subtradição Seridó (Figura 25), nos quais é possível perceber a presença de antropomorfos representando, não somente crianças envolvidas em composições que se repetem em vários abrigos, como também, a representação de todos os estágios reprodutivos: a cópula, a gestação, o nascimento e estágios perinatais (MARTIN, 2008).
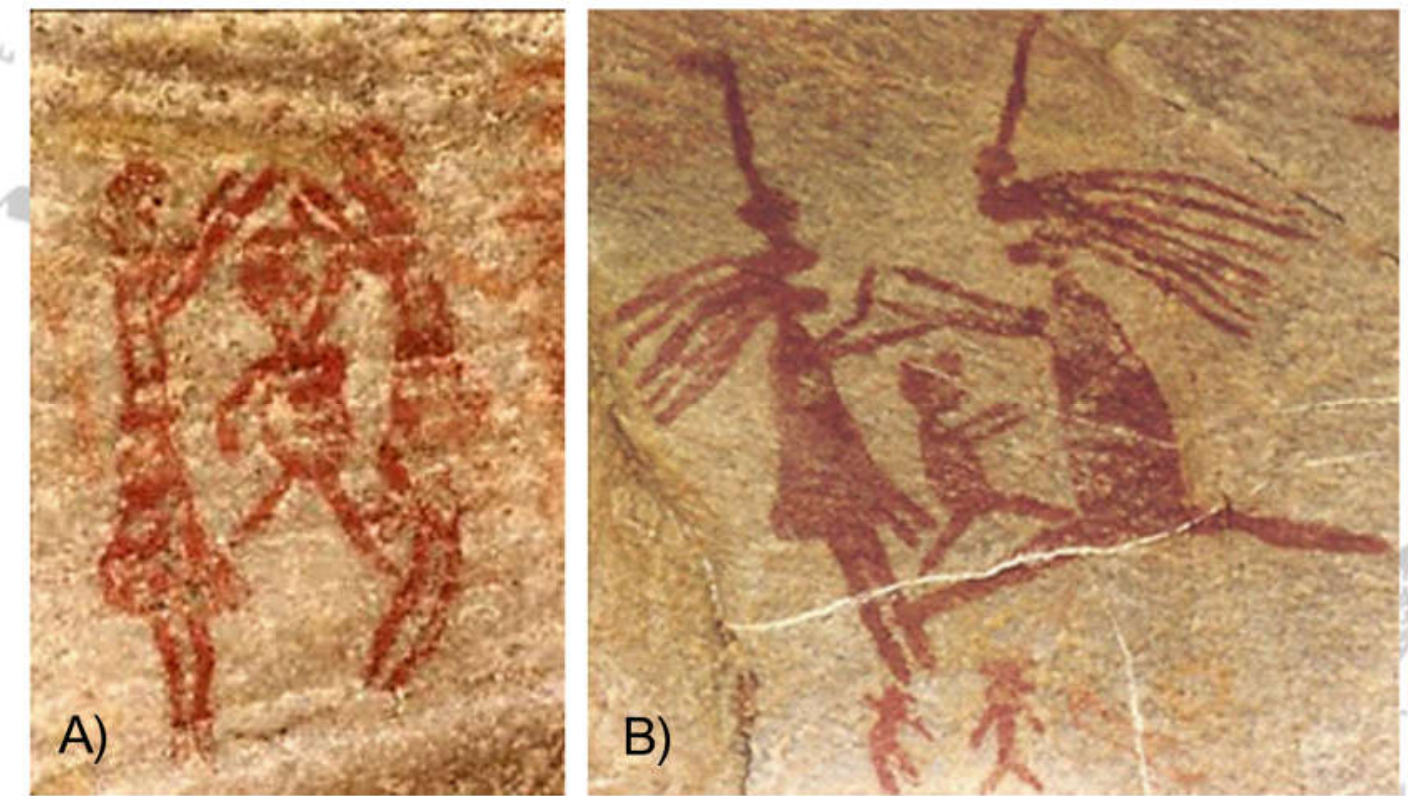

Figura 25 - Grafismos emblemáticos da Tradição Nordeste, Subtradição Seridó. Cena "familiar", com representação de gênero e infância. Sítio arqueológico Xique-xique IV (A e B). Área arqueológica do Seridó, RN, Brasil. (Fonte: internet).

Os dados antropométricos (ALVIM et al., 1990; SOLARI et al., 2016(b)) apontam para uma diversidade morfológica dos indivíduos analisados. A predominância da dolicocefalia, em relação a braquicefalia, além de outras características observadas, 
indicam associações com a população de Lagoa Santa. Entretanto, o alto índice de variações individuais e os poucos dados métricos presentes nos remanescentes ósseos, impossibilitam uma análise comparativa mais acurada (SILVA et al., 2020). Todavia, esta variação morfológica coincide com a diversidade populacional observada no sítio mexicano Quintana Roo, datado na transição PleistocenoHoloceno e no Holoceno Inferior (HUBBE et al., 2019). Por sua vez, os dados odontométricos, demonstram a ocorrência de incisivos em forma de pá, o que confirma a ancestralidade americana para a população do Pedra do Alexandre. Além disso, foi observado intenso desgaste dentário, relacionado a atividades mastigatórias e extra mastigatórias - tanto em indivíduos adultos, como em indivíduos subadultos. Este fato indicou uma dieta abrasiva, na qual as crianças eram introduzidas desde primeiros anos de vida, sugerindo desmame prematuro, entre um (01) e três (03) anos de idade (SOLARI et al.., 2016(b)).

A revisão e síntese dos dados acumulados ao longo de vinte e um (21) anos de intervenção arqueológica, viabilizaram identificação de novos tipos de inumação, a divulgação do resultado de novas datações realizadas e uma periodização das práticas funerárias atualizada. $\mathrm{O}$ sepultamento $25 \mathrm{e}$, possivelmente o sepultamento 23, ambos primários e simples, foram inumados no interior de nichos formados por blocos caídos, com os corpos distendidos e os membros, superiores e inferiores dispostos ao longo do corpo. As estruturas funerárias identificadas durante as campanhas iniciais do sítio, não apresentaram esta disposição do corpo: os sepultamentos primários exumados, apresentaram corpos e membros fletidos, em 
decúbito lateral, e foram inumados em espaços cada vez mais restritos, ao ponto de necessitar do peso de blocos líticos, para manutenção dos cadáveres na área escolhida para deposição. Como é possível perceber nos sepultamentos: sepultamento 2 e sepultamento 7 (ver Figura 18).

O outro tipo de deposição funerária observado, diz respeito a redução dos corpos por meio do fogo. As estruturas de combustão, anteriormente descritas como fogueiras rituais (MARTIN, 2008), apresentaram feições similares àquelas registradas no sítio Furna do Umbuzeiro (BORGES, 2010). Neste último, a coleta de fragmentos ósseos humanos, com sinais de queima e marcas de corte (SILVA, 2018), sugerem a manipulação, o descarne e o possível consumo ritualizado da carne dos mortos. Nesse sentido, a cremação e o endocanibalismo podem estar representados nos níveis de ocupação mais superficiais do sítio, após o abandono das inumações, a partir de \pm 2600 anos AP.

No registro arqueológico sul-americano, o canibalismo em contextos funerários já foi diversas vezes descrito (STRAUSS, 2010). Entretanto, a dificuldade de diferenciar este tipo de ritual daqueles em que a manipulação e a secundarização cadavérica prescindiam do consumo da carne, induz a não considerar esta, uma interpretação válida para depósitos funerários (ARENS, 1979; BOTELLA et al., 1999). Porém, o registro etnohistórico do Seridó potiguar, dos séculos XVII e XVIII, descreve uma população caçadora-coletora, com cultura material e comportamentos culturais que permitem estabelecer paralelos com o registro 
arqueológico (BORGES, 2010). Esta população praticava rituais funerários que privilegiavam a redução e o consumo de todos os remanescentes orgânicos dos mortos.

Denominada, no registro histórico como Tarairiú, era constituída por diversas etnias, unificadas por uma língua isolada comum (MEDEIROS FILHO, 1984; CUNHA, 1998; PUNTONI, 1998; LOPES, 1999; TEENSMAN, 2000; MEDEIROS, 2002; PIRES, 2002; POMPA, 2003; FERNANDES, 2004; SANTOS JR., 2008) e, com profundidade temporal de \pm 9000 anos AP (URBAN, 1998). Por esse motivo, foi proposta uma relação de identidade, entre o registro arqueológico e o registro etnohistórico, que permitiu a definição de um horizonte cultural, de longa duração temporal, para a área arqueológica do Seridó (BORGES, 2020). As novas datas estimadas, mediante datações radiocarbônicas calibradas, a partir de amostras coletadas nas estruturas arqueológicas escavadas nas XVI e XVII campanhas, permitiram um recuo cronológico de, pelo menos, mil e quinhentos (1500) anos, para o início das práticas funerárias e práticas gráficas, no assentamento: \pm 10600 anos $\mathrm{AP}$ (calibração do $\mathrm{C}^{14}$ ): sepultamento $23 ; \pm 10500$ anos AP (calibração do $\mathrm{C}^{14}$ ): estrutura lítica com vestígios de práticas gráficas, associada a fragmentos de óxido de ferro com marcas de uso.

Paralelamente, foi possível propor uma periodização atualizada para as práticas funerárias do sítio, baseada não somente em intervalos cronológicos, como também, na variação formal dos tipos de inumação, acima descritos. No primeiro período, 
datado entre $9440 \pm 40$ (Cal AP 10750 a 10580 - Beta-327693 e 9400 \pm 90 (CSIC1051), verificou-se presença de inumações primárias simples, em decúbito dorsal e/ou lateral, com membros estendidos ao longo do corpo e deposição em nichos preexistentes, formados por blocos caídos e acomodados no interior do abrigo. Não se descarta a ocorrência de outros tipos de deposições neste intervalo temporal, mas a posição estendida dos corpos e membros é exclusiva deste período, como é possível perceber nos sepultamentos 3, 23, 25 e 26. O segundo momento foi datado entre 8280 \pm 30 (CSIC-965) e 2620 \pm 60 (CSIC-1061). Localizados nos setores logo abaixo do painel rupestre do sítio, caracterizam-se como: (a) inumações primárias simples e coletivas, com corpos e membros flexionados e a presença de acompanhamentos funerários; (b) inumações secundárias, igualmente simples e coletivas, com a presença de pigmento vermelho sobre os ossos e acompanhamentos funerários. Marcadores ósseos de alteração térmica (sinais de queima) e outros tipos de manipulação estão presentes em alguns remanescentes ósseos humanos deste período, que abrange a maioria das deposições funerárias registradas no sítio e o maior índice de variação tipológica. E, derradeiramente, o período final, datado apenas pelo abandono das inumações funerárias no assentamento - a partir de 2500 anos AP. Apesar de ainda ser totalmente hipotético, caracteriza-se pela substituição de sepultamentos pela cremação, como prática funerária predominante. $\mathrm{O}$ intervalo de \pm 4000 anos $\mathrm{AP} \mathrm{a} \pm 1100$ anos $\mathrm{AP}$, determinado pela cronoestratigrafia do sítio Furna do Umbuzeiro (BORGES, 2010; SILVA, 2018), sugere que inumação e cremação podem ter sido realizadas 
concomitantemente, tanto no Pedra do Alexandre, como em outros sítios arqueológicos.

Através da correlação dos resultados de datações recentemente determinadas, foi possível estabelecer uma cronologia relativa, para um importante evento ocorrido no sítio em questão: o colapso parcial do abrigo. Os setores selecionados para realização das intervenções arqueológicas da XVI e XVII campanhas arqueológicas, já haviam sido escavados em etapas anteriores. Depositados em maior profundidade, tais níveis arqueológicos e estruturas funerárias apresentaram um menor índice de alteração decorrente da queda de blocos, sugerindo que as inumações foram realizadas em períodos anteriores ou contemporâneos ao desmoronamento do teto. Isto permitiu estimar uma cronologia para o evento, assim como, explicar a situação estratigráfica e os agentes pós-deposicionais que atuaram sobre as estruturas funerárias e outros vestígios arqueológicos, na porção oeste do abrigo. Localizado no intervalo temporal entre \pm 10000 anos e \pm 8000 anos, o colapso e desmoronamento do teto do abrigo foi condicionante para as ocupações subsequentes do sítio, determinando uma redução do espaço funerário e, possivelmente, uma redução no espaço utilizado nas atividades gráficas. Este fato pode ser verificado pela mudança nos tipos de inumação, datadas após \pm 9000 anos AP.

A reconstituição paleoambiental, viabilizada pela realização de análises sedimentológicas e análises zooarqueológicas preliminares, descrevem um 
ambiente mais úmido e um adensamento da cobertura vegetal, que se consolidou durante a transição Pleistoceno-Holoceno. O aumento das precipitações e o maior índice de umidade favoreceram a estabilização de uma vegetação, predominantemente florestal, durante o Holoceno Inferior e o início do Holoceno Médio (MUTZENBERG, 2007). Os remanescentes ósseos não humanos descrevem uma fauna diversificada, com o registro de espécies ainda presentes e adaptadas a um clima semiárido e espécies adaptadas a climas tropicais e tropicais úmidos (MARTIN, 2008; QUEIROZ et al., 1996). Esta situação ambiental, apesar da aridez regional característica do Holoceno Superior, manteve-se estável até períodos relativamente recentes, dadas as características estruturais do próprio rio Carnaúba, as quais garantem a formação de reservas hídricas subterrâneas em seu lençol freático (MUTZENBERG, 2007).

Com o desenvolvimento das pesquisas, na área arqueológica do Seridó, foi possível identificar sítios lito-cerâmicos a céu aberto e em abrigos rochosos não utilizados para deposições funerárias e atividades gráficas. As datas obtidas permitem relacionar estes assentamentos, com a cronoestratigrafia definida para o Pedra do Alexandre: \pm 4000 anos AP a \pm 900 anos AP. As análises laboratoriais, nos conjuntos vestigiais coletados, permitiram estabelecer relações tecnológicas, entre os perfis técnicos líticos e cerâmicos, tanto de sítios a céu aberto - sítios Baixa do Umbuzeiro I e II, Meggers I e III, Pereira II e Alto dos Marcolinos -; como de sítios abrigados - sítios Furna do Umbuzeiro, Olho d'Água das Gatas, Pedra do Chinelo e Pedra do Alexandre. Isto sugeriu a proposição de um horizonte cultural 
compartilhado, o qual não apresentaria grandes variações espaço-temporais ou rupturas evidentes, no registro arqueológico (BORGES, 2010; ALMEIDA, 2014; NOGUEIRA, 2017).

No que diz respeito às indústrias líticas analisadas, o perfil técnico definido não apresentou diferenças nas técnicas e nos métodos aplicados, nos dois tipos de assentamento: sítios a céu aberto e sítios em abrigo. Entretanto, a definição deste perfil técnico desconsiderou a disposição estratigráfica do universo de análise: tanto para vestígios provenientes de abrigos rochosos, onde estes dados estão disponíveis; como para aqueles coletados em sítios a céu aberto, onde não foram registrados através de intervenções subsuperficiais. De forma que, associado ao conceito de curadoria aplicado nas metodologias de análise e na seleção das amostras, agregou uma ideia de contemporaneidade ao material analisado, consequentemente considerado, como resultado de uma única ocupação.

Um fato aqui percebido, no conjunto de estudos e análises realizados no sítio Pedra do Alexandre, foi o desinteresse no material cerâmico como vestígio relevante, para elucidar os processos culturais ocorridos nos grupos humanos que o selecionaram, como espaço para realização de práticas gráficas, práticas mortuárias e atividades de subsistência. Considerando o contexto cultural caçador-coletor e os tipos de vestígios teoricamente relacionados a estas populações, não é surpreendente esta imprevisão. Entretanto, somente o fato de sua existência, vinculada a estes grupos 
culturais, por si só já demonstra a relevância e a necessidade de estudos sobre o desenvolvimento da tecnologia ceramista em economias caçadoras-coletoras.

Este fato pode ser percebido, em publicação recente sobre o sítio, que teve como enfoque os estudos antropométricos do considerável número de sepultamentos infantis evidenciados. Nestas, assume-se que: "no sítio em uma faixa extensa de tempo, que se estende a pouco mais de $9400 \pm 35$ A.P. a $2620 \pm 60$ A.P., envolvendo ciclos funerários e populações que não teriam deixado artefatos cerâmicos, mas pinturas rupestres no contexto arqueológico do sítio" (SOLARI et al., 2016(a), 28). Esta afirmação, como visto, não condiz com a realidade do registro arqueológico do assentamento, dada a presença, mesmo tímida, do material cerâmico em uma faixa cronológica que se estende de $\pm 2800 \mathrm{AP} \mathrm{a} \pm 2600 \mathrm{AP}$. O caso de, não haver fragmentos cerâmicos em associação direta às práticas funerárias, ou mesmo práticas rupestres, não nega os impactos da introdução de uma nova tecnologia, nos mais diversos aspectos da vida social destes agrupamentos humanos.

O registro e a análise de sítios a céu aberto, classificados como áreas habitacionais e acampamentos temporários, com relações tecnológicas de identidade com o material arqueológico coletado em sítios abrigados (BORGES, 2010, ALMEIDA, 2014; NOGUEIRA, 2017), demonstra a introdução da tecnologia ceramista, neste contexto caçador-coletor, em \pm 3000 anos AP $( \pm 2700$ anos AP - NOGUEIRA, 2017). Sua presença em tais assentamentos, relacionados a atividades de subsistência, sugere o tipo de uso do vasilhame cerâmico registrado e o valor 
simbólico atribuído. A ausência de associação entre material cerâmico, práticas mortuárias e gráficas, associada a baixa densidade do vestígio, reforça classificação funcional proposta, para os dois tipos de assentamento: habitacional, temporário e vinculado a atividades de subsistência, para sítios a céu aberto; e simbólica/ritualística, temporário e vinculado a práticas gráficas e mortuárias, para os sítios em abrigo rochoso.

No que se relaciona ao problema de sua introdução, na área arqueológica do Seridó, as relações tipológicas entre este conjunto cerâmico e as cerâmicas amazônicas mais antigas - Tradição Mina, por exemplo (BROCHADO, 1984) - não apontam para um desenvolvimento autóctone. $\mathrm{O}$ aparecimento repentino, tanto na estratigrafia dos sítios abrigados, como na dos sítios a céu aberto - Meggers III (NOGUEIRA, 2017) -, reforçam a hipótese de difusão de traço cultural, entre grupos caçadores-coletores, sem necessariamente haver ocorrido um contato direto entre estas populações.

Contudo, esta afirmação ainda não pode ser definitivamente confirmada. O registro de níveis arqueológicos relacionados a um horizonte cultural caçador-coletor no sítio Jacinto I, na Colômbia, com a presença de fragmentos cerâmicos e fornos subterrâneos preenchidos com argila crua, datados entre \pm 5190 anos $\mathrm{AP} e \pm 5940$ anos AP, indicam o uso antigo da cerâmica e dissociado do desenvolvimento de práticas agrícolas (OYUELA-CAYCEDO, 2006). Paralelamente, pesquisas desenvolvidas na região amazônica, têm demonstrado a possibilidade de vários 
centros autônomos, de desenvolvimento para tecnologia ceramista (BARRETO et al., 2016; NEVES, 2016), o que coloca em cheque as proposições difusionistas, que indicavam seu desenvolvimento em sambaquis fluviais, a partir da Tradição Mina (BROCHADO, 1984); ou hiperdifusionistas, que previam uma introdução da cerâmica Valdívia, da Polinésia para a América do Sul, via oceano Pacífíco (MEGGERS, 1979).

A descrição do uso de argila crua em fornos subterrâneos para a preparação de alimentos, no sítio Jacinto I, suscita esta dúvida. Logo, é possível que um tipo de tecnologia de cozimento similar poderia estar em uso no Pedra do Alexandre. Como consequência direta de sua aplicação, numa simples relação de causa e efeito, a hipótese do desenvolvimento autóctone da tecnologia ceramista, na área arqueológica do Seridó, não pode ser descartada. A não identificação de indícios dos estágios iniciais de seu desenvolvimento, nos sítios já escavados, não significa sua inexistência. Porém, esta é uma questão que só pode ser solucionada, com o andamento das pesquisas e o registro de novos assentamentos.

Como foi possível verificar, os dados arqueológicos, os dados etnohistóricos e os dados linguísticos permitem a proposição de um horizonte cultural comum, para a área arqueológica do Seridó. Apesar do caráter propositivo destas interpretações, da impossibilidade de verificação objetiva com os dados atualmente disponíveis, é possível estabelecer algumas considerações que podem conduzir 0 desenvolvimento de pesquisas futuras. No que diz respeito ao tipo cultural, o 
estabelecimento de uma economia caçadora-coletora, no Holoceno Inferior, garantiu a sobrevivência destas populações, até o momento dos primeiros contatos coloniais - século XVII - sem profundas alterações na sua organização social e modos de subsistência, mesmo com o advento da tecnologia ceramista, há \pm 3000 anos AP. Quanto à mobilidade espacial, a inexistência de dados paleobotânicos, palinológicos e antracológicos, não permite determinar a sazonalidade das ocupações, nos assentamentos analisados. No entanto, a recorrência temporal da função funerária, no sítio Pedra do Alexandre, em associação aos dados etnohistóricos disponíveis, permitem supor uma mobilidade logística, com o manejo de um amplo território, com recursos diversificados e sazonalidade anual regular (NOGUEIRA, 2017).

Da maneira similar a outras áreas arqueológicas da América do Sul, o desenvolvimento ou a aquisição da tecnologia ceramista, até o momento, não pode ser vinculado a atividades de processamento e manejo vegetal e, muito menos, ao investimento na produção recursos vegetais, mediante agricultura. Da mesma forma, o registro documental descreve uma economia baseada na caça, na coleta de recursos vegetais silvestres e na exploração melífera de abelhas nativas. Às vezes chamados de "populações do mel", os Tarairiú produziam uma bebida fermentada a base de mel (MEDEIROS FILHO, 1984; PIRES, 2002; POMPA, 2003; FERNANDES, 2004), que pode explicar a adoção da cerâmica nesta cadeia operatória, em detrimento do desenvolvimento de técnicas agrícolas ou de manejo 
vegetal. Entretanto, esta é uma proposição ainda não verificável, com o nível de dados disponíveis no registro arqueológico.

A diversidade tipológica das práticas funerárias verificadas, está inserida no contexto mais amplo do continente sul-americano. A coexistência de diversos tipos de inumação, em um mesmo horizonte cultural, e a seleção de "pontos notáveis" na paisagem, transformados em "lugares persistentes", pela realização recorrente de deposições funerárias, adequa-se aos novos dados disponíveis, para as práticas funerárias de caçadores-coletores (STRAUSS, 2010). É interessante ressaltar, que o aumento da variação tipológica no Pedra do Alexandre, ocorreu após o colapso parcial do abrigo, quando processos de secundarização mais complexos e inumações primárias em espaço reduzido foram registrados nas estruturas funerárias escavadas.

A possibilidade do registro de práticas crematórias, é outro fator que aponta para uma variação temporal das práticas funerárias. Esta interpretação é sustentada pela identificação de marcas de corte e sinais de queima, em fragmentos ósseos humanos coletados no interior de estruturas de combustão - "fogões" - no sítio Furna do Umbuzeiro. Além disso, a descrição de "concreções de calcário" associadas a estruturas de combustão, nas planilhas de etiquetas do Pedra do Alexandre, pode relacionar este indício ao registro de hidroxiapatita, verificado no sítio citado. Como subproduto de calcinação de remanescentes ósseos, esta proteína foi um indicativo que permitiu identificar práticas crematórias, no assentamento (SILVA, 2018). 
Estas hipóteses foram formuladas com base no registro documental. A descrição das práticas funerárias, das populações indígenas que viviam na área arqueológica do Seridó, no período colonial, associam o endocanibalismo aos Tarairiú históricos. Nesse sentido, o uso das fontes históricas foi determinante na formulação de interpretações, que só podem adquirir confiabilidade, caso sejam verificadas no registro arqueológico. Logo, antes de paralelo etnográfico, a confluência cultural, espacial, cronológica e material destes dados, provenientes de ramos interligados das ciências humanas - a arqueologia, a etnohistória e a linguística -, permite estabelecer as correlações sugeridas, para a caracterização de enclaves préhistóricos, na região.

A proposição de uma linha de pesquisa nestes moldes, não é inédita na arqueologia brasileira. Em desenvolvimento na região amazônica, desse o início do século XXI (NEVES, 1999, 2000), esta abordagem metodológica tem demonstrado sequências de ocupação, mesmo com a ocorrência de migrações e mudanças espaciais, que atravessam continuamente, todo o Holoceno (NEVES et al., 2020). Apesar de hiatos cronológicos durante o Holoceno Médio - também observados na cronoestratigrafia do Pedra do Alexandre (MUTZENBERG, 2007) - é possível verificar:

"uma longa história de ocupação (...); a formação de solos de terras pretas [indígenas] há pelo menos 3.500 BCE [5500 anos AP]; e, já no primeiro milênio CE [1000 anos AP], a 
manifestação de um padrão de diversidade cultural, atestado por diferentes conjuntos cerâmicos contemporâneos, justapostos na mesma área.” (NEVES et al., 2020: 02).

Considerando a diversidade étnica, linguística e o grande número de horizontes culturais definidos na região amazônica, não parece absurda, a adaptação desta metodologia, para as pesquisas arqueológicas no Seridó. Apesar de não lidar com populações originárias contemporâneas, que poderiam atestar, através da tradição oral relações de ancestralidade com vestígios arqueológicos (NEVES, 1999, 2000; NEVES et al., 2020), os dados etnohistóricos do Seridó potiguar descrevem uma situação etnográfica mais simples, com o registro de apenas uma língua isolada e um grupo cultural bem delimitado, para confrontação com o registro arqueológico. Mesmo considerando a fragilidade do vestígio para definição de fronteiras étnicas, a arqueologia pode fornecer bons resultados, quando analisa processos de longa duração (NEVES, 1999).

Logo, a associação entre Arqueologia, Linguística e registros históricos tornou viável a proposição do horizonte cultural, aqui proposto. Em outras palavras, partese do pressuposto que a pré-história sul-americana é a história profunda das populações indígenas (BROCHADO, 1984) e que, o objetivo da arqueologia brasileira é o resgate desta história nativa, de longa duração (NEVES, 2000). Logo, não relacionar dados provenientes das disciplinas aqui elencadas, impede a formulação de hipóteses interpretativas e o desenvolvimento de uma linha de pesquisa que permitam responder aos problemas do desenvolvimento cultural, das 
filiações culturais e o impacto da colonização europeia, nas populações originárias da América do Sul.

\section{REFERÊNCIAS BIBLIOGRÁFICAS}

ALMEIDA, M. d'A. 2014. Análises tecnológicas e funcionais das indústrias líticas de quatro sítios arqueológicos do Seridó Potiguar. Dissertação de Mestrado, Programa de Pósgraduação em Arqueologia, Universidade Federal de Pernambuco, Recife.

ALVIM, M. C. M.; SOUZA, Sheila M. F. M. 1990. "Relações biológicas entre populações indígenas atuais e pré-históricas do Brasil". Clio: Série Arqueológica, v. 1 (6), 69-79.

ALVIM, M. C. M.; UCHÔA, D. P.; SILVA, S. F. S. M. (1995-1996). "Osteobiografia da população pré-histórica do abrigo Pedra do Alexandre, Carnaúba dos Dantas, RN". Clio: Série Arqueológica, v. 1 (11), 17-42.

ARENS, William. 1979. The man-eating mith: Anthropology and Anthropophagy. Oxford: Oxford University Press.

BARLEUS, G. 1980. História dos feitos recentemente praticados durante oito anos no Brasil. Recife: Fundação de Cultura da Cidade do Recife.

BARRETO, C; LIMA, H. P.; BETANCOURT, C. J. (Orgs.). 2006. Cerâmicas arqueológicas da Amazônia: rumo a uma nova síntese. Belém: IPHAN: Ministério da Cultura.

BINFORD, L. R. 1971. "Mortuary Practices: their study and their potencial". In: BROWN, J. (Ed.). Aproaches to the social dimension of mortuary practices. Memoir of the Society for American Archaeology, n. 25 (6-29). Disponível em: https://www.jstor.org/stable/25146709?origin=JSTORpdf\&seq=1\#page_scan_tab_contents. Acesso em: 17 jun. 2020.

BINFORD, L. R. 1980. "Smoke and dogs' tails: hunter-gatherer settlement system and archaeological site formation". American Antiquity, [s.i.], v. 45, (1), 4-20. Disponível em: 
http://citeseerx.ist.psu.edu/viewdoc/download?doi=10.1.1.614.4810\&rep=rep1\&type=pdf Acesso em: 15 de abr. 2008.

BIRD, J. B. 1988. Travel and archaeology in South Chile. Iowa City: University of Iowa.

BORGES, F. M. 2008. “Endocanibalismo na Área Arqueológica do Seridó?”. Clio: Série Arqueológica, $\quad$ v. 23, (1), 18-35. Disponível em: https://periodicos.ufpe.br/revistas/clioarqueologica/article/view/246828 Acesso em: 01 mar. 2019.

BORGES, F. M. 2010. Os sítios arqueológicos Furna do Umbuzeiro e Baixa do Umbuzeiro: caracterização de um padrão de assentamento na Área Arqueológica do Seridó - Carnaúba dos Dantas - RN, Brasil. Tese de Doutorado, Programa de Pós-Graduação em Arqueologia, Universidade Federal de Pernambuco, Recife.

BORGES, F. M. 2020. "Proposta para uma abordagem arqueológica da etno-história do Seridó - RN/PB: Proposal for an archaeological approach of the ethnohistory of Seridó RN/PB". Revista Nordestina de História do Brasil, v. 2 (4), 84-103. Disponível em: https://www3.ufrb.edu.br/seer/index.php/historiadobrasil/article/view/1924 Acesso em: 08 de mar. 2020.

BOTELlA, M. C.; ALEMÁN, I.; JiMÉNEZ, S. A. 1999. Los huesos humanos: manipulación y alteraciones. Barcelona: Edicions Bellaterra.

BRANDT, S. A. 1988. "Early Holocene mortuary practices and hunter-gatherer adaptation in Southern Somalia". World Archaeology, [s.i.], n. 20, 40-56. Disponível em: https://www.researchgate.net/publication/51373731_Early_Holocene mortuary practices and hunter-gatherer adaptations in southern Somalia Acesso em: 05 set. 2018.

BROCHADO, José P. 1984. An ecological model of the spread of pottery and agriculture in to Eastern South America. Tese de Doutorado, University of Illinois at UrbanaChampaign, Urbana.

CASTRO, V. M. C. 2009. Marcadores de identidades coletivas no contexto funerário préhistórico no Nordeste do Brasil. Tese de Doutorado, Programa de Pós-Graduação em Arqueologia, Universidade Federal de Pernambuco, Recife. 
CHAPMAN, R. 2003. "Death, society and Archaeology: social dimensions of mortuary practices". Mortality, Reading/UK, v. 8 (3), 305-312. Disponível em: http://users.clas.ufl.edu/davidson/arch\%20of\%20death/Week\%2015/Chapman\%202003\% 20Social\%20dimensions.pdf Acesso em: 05 set. 2018.

CHARLES, D. K.; BUIKSTRA, J. E. 1983. "Archaic mortuary sites in the Central Mississipi dainage: distribuition, structure and behavioral implications". In: PHILLIPS, J. L.; BROWN, J. A. (Eds.): Archaic hunter and gatherer in the American Midwest. New York: Academic Press, 117-144.

CUNHA, M. C. (Org.). 1998. História dos índios do Brasil. São Paulo: Companhia. das Letras.

FERNANDES, J. A. 2004. Selvagens bebedeiras: álcool, embriaguez e contatos culturais no Brasil Colonial. Tese de Doutorado, Programa de Pós-Graduação em História, Universidade Federal Fluminense, Rio de Janeiro.

FONTES, M. A. F. 2003. A cerâmica pré-história da área arqueológica do Seridó-RN. Dissertação de Mestrado, Programa de Pós-Graduação em História, Universidade Federal de Pernambuco, Recife.

HUBBE, M.; NEVES, W. A.; LICURGO, H.; GUIDON, N. 2007. "Brief communication: 'Zuzu' strikes again - morphological affinities of the early Holocene human skeleton from Toca dos Coqueiros, Piaui, Brazil”. 2003, [s.i.], v. 134 (2), 285-291.

LITTLETON, J. 2002. "Mortuary Behavior on the Hay Plain: do the cemetery exist?". Archaeology of Oceania, [s.i.], v. 37 (3), 105-122. Disponível em: https://www.jstor.org/stable/40387222 Acesso em: 05 set. 2018.

LITTLETON, J.; ALLEN, H. 2007. "Hunter-gatherer Burials and criation of persistent places in Southeastern Australia". Journal of Anthropological Archaeology, v. 26, 283-298. Disponível em: https://bap.artsrn.ualberta.ca/Workshop2010/resources/5/Littleton_Allen.pdf Acesso em: 05 set. 2018. 
LOPES, F. M. 1999. Missões religiosas: índios, colonos e missionários na colonização do Rio Grande do Norte. Dissertação de Mestrado, Programa de Pós-Graduação em História, Universidade Federal de Pernambuco, Recife.

MAFRA, F.; MARTIN, G.; NOGUEIRA, M. 2015. "Intervenções arqueológicas em sítios a céu aberto na área arqueológica do Seridó: os sítios Meggers I e Meggers III, Parelhas RN, Brasil”. Clio: Série Arqueológica, Recife, v. 30 (1), 10-37.

MAFRA, F.; MARTIN, G.; NOGUEIRA, M. 2016. "Sítios a céu aberto na região do Seridó Potiguar: um estudo de caso do Rio da Cobra, entre os municípios de Carnaúba dos Dantas e Parelhas - RN". Clio: Série Arqueológica, Recife, v. 31 (3), 113-132.

MARTIN, G. 1985. "Arte rupestre no Seridó (RN); o sítio "Mirador" no Boqueirão de Parelhas". Clio: Série Arqueológica, Recife, v. 2 (7), 81-95. Disponível em: https://periodicos.ufpe.br/revistas/clioarqueologica/article/view/247240 Acesso em: 01 mar. 2019.

MARTIN, G. 1989. "A subtradição Seridó de pintura rupestre pré-histórica do Brasil”. Clio: Série Arqueológica, Recife, n. 5, 19-26. Disponível em: https://periodicos.ufpe.br/revistas/clioarqueologica/article/view/247214 Acesso em: 01 mar. 2019.

MARTIN, G. 1993. "Arte rupestre e registro arqueológico no Nordeste do Brasil”. Clio: Série Arqueológica, Recife, n. 9, 45-56. Disponível em: https://periodicos.ufpe.br/revistas/clioarqueologica/article/view/247156 Acesso em: 01 mar. 2019.

MARTIN, G. 1994. “Os rituais funerários na pré-história do Nordeste”. Clio: Série Arqueológica, Recife v. 1, (10), 29-46. Disponível em: https://periodicos.ufpe.br/revistas/clioarqueologica/article/view/247124 Acesso em: 01 mar. 2019.

MARTIN, G. 1995-1996. "O cemitério Pré-histórico "Pedra do Alexandre” em Carnaúba dos Dantas, RN". Clio: Série Arqueológica, Recife, n. 11, 43-57. Disponível em: https://periodicos.ufpe.br/revistas/clioarqueologica/article/view/247078 Acesso em: 01 mar. 2019. 
MARTIN, G. 1996. "Os sítios rupestres no Seridó, no Rio Grande do Norte (Brasil) no contexto do povoamento da América do Sul". FUMDHAMentos, São Raimundo Nonato/PI, v. 1 (1), 339-346. (Número dedicado à publicação dos Anais da Conferência Internacional sobre o Povoamento das Américas, de 1996). Disponível em: https://drive.google.com/file/d/1 Y9xLm9GqU56mClkcNecZG9J8gLQ19qc/view Acesso em: 01 mar. 2019.

MARTIN, G. 2003. "Fronteiras estilísticas e culturais na arte rupestre da área arqueológica do Seridó (RN, PB)". Clio: Série Arqueológica, Recife, n. 16 (11-31). Disponível em: https://periodicos.ufpe.br/revistas/clioarqueologica/article/view/246968 Acesso em: 01 mar. 2019.

MARTIN, G. 2008. Pré-história do Nordeste do Brasil. Recife: Editora UFPE.

MARTIN, G.; GUIDON, N. 2010. “As onças e as orantes: uma revisão das classificações tradicionais dos registros rupestres no NE do Brasil". Clio: Série arqueológica, Recife, v. 25 (1), 11-30. Disponível em: https://periodicos.ufpe.br/revistas/clioarqueologica/article/view/246813 Acesso em: 01 mar. 2019.

MARTIN, G. ASÓN-VIDAL, I. 2014. "Dispersão e difusão das tradições rupestres no Nordeste do Brasil. Vias de ida e volta?”. Clio: Série Arqueológica, Recife, v. 29 (2), 1528.

https://periodicos.ufpe.br/revistas/clioarqueologica/article/view/246598 Acesso em: 01 mar. 2019.

MEDEIROS FILHO, O. 1984. Índios do Açu e Seridó. Brasília: Editora do Senado.

MEDEIROS, R. P. 2002. "Povos indígenas do sertão nordestino no período colonial: descobrimentos, alianças, resistências e encobrimento". FUMDHAMentos, São Raimundo Nonato, v. 1 (2), 09-52.

MEGGERS, B. J. 1979. América pré-histórica. Tradução Eliane Teixeira de Carvalho. Rio de Janeiro: Paz e Terra. 
MOREAU, P.; BARO, R. 1979. História das últimas lutas no Brasil entre holandeses e portugueses \& relação da viagem ao país dos Tapuias [1647]. Belo Horizonte: Itatiaia; São Paulo: Editora USP.

MÜTZENBERG, D. S. 2007. Gênese e ocupação pré-histórica do Sítio Arqueológico Pedra do Alexandre: uma abordagem a partir da caracterização paleoambiental do vale do Rio Carnaúba - RN. Dissertação de Mestrado, Programa de Pós-Graduação em Arqueologia, Universidade Federal de Pernambuco, Recife.

NEVES, E. G. 1999. “Arqueologia, História Indígena e registro etnográfico: exemplos do Alto Rio Negro". Revista do Museu de Arqueologia e Etnologia, São Paulo, s. 3, 319-330. Disponível em: https://www.revistas.usp.br/revmaesupl/article/download/113476/111431 Acesso em: 09 jul. 2020.

NEVES, E. G. 2000. “O velho e o novo na Arqueologia amazônica”. Revista USP, São Paulo, n. 44, 86-111. Disponível em: https://www.revistas.usp.br/revusp/article/download/30096/31981/ Acesso em: 09 jul. 2020.

NEVES, E. G. 2006. "Não existe neolítico ao Sul do Equador: as primeiras cerâmicas amazônicas e a sua falta de relação com a agricultura". In: BARRETO, C; LIMA, H. P.; BETANCOURT, C. J. (Orgs.). Cerâmicas arqueológicas da Amazônia: rumo a uma nova síntese. Belém: IPHAN: Ministério da Cultura, 32-39.

NEVES, E. G.; WATLING, J.; ALMEIDA, F. O. 2020. “Arqueologia do Alto Madeira no contexto arqueológico da Amazônia". Boletim do Museu Paraense Emílio Goeldi, Belém, v. $\quad 15 \quad(2 \quad-\quad$ e20190081), 1-20. Disponível em: https://www.scielo.br/pdf/bgoeldi/v15n2/1981-8122-bgoeldi-15-2-e20190081.pdf Acesso em: 09 jul. 2020.

NOGUEIRA, M. 2017. Ocupações pré-históricas a céu aberto no vale do Rio da Cobra Carnaúba dos Dantas e Parelhas - RN. Tese de Doutorado, Programa de Pós-Graduação em Arqueologia, Universidade Federal de Pernambuco, Recife. 
OYUELA-CAYCEDO, A. 2006. "El contexto económico de la alfarería temprana en el caso de San Jacinto 1". Boletín de Arqueología PUCP, Lima, n. 10, 285-304. Disponível em: http://revistas.pucp.edu.pe/index.php/boletindearqueologia/article/view/1656 Acesso em: 09 jul. 2020.

PARDOE, C. 1988. "The cemetery as symbol. the distribuition of prehistoric Aboriginal burial grounds in Southeastern Australia". Archaeology of Oceania, [s.i.], v. 23 (1), 1-178. Disponível em: https://onlinelibrary.wiley.com/doi/abs/10.1002/j.18344453.1988.tb00178.x Acesso em: 05 set. 2018.

LITTLETON, J. 2002. "Mortuary Behavior on the Hay Plain: do the cemetery exist?". Archaeology of Oceania, [s.i.], v. 37 (3), 105-122.

PETTITT, P. 2011. The Paleolithic origins of human burial. London: Routledge.

PIRES, M. I. C. 2002. A Guerra dos Bárbaros: resistência e conflitos no Nordeste colonial. Recife: Editora UFPE.

POMPA, C. 2003. Religião como tradução: missionários, Tupi e Tapuia no Brasil Colonial. Bauru: EDUSC.

POMPEU SOBRINHO, T. 1934. Os tapuias do Nordeste e a monografia de Elias Herckman. Revista do Instituto do Ceará, Fortaleza, t. 48, 07-28. Disponível em: http://www.ceara.pro.br/Instituto-site/Rev-apresentacao/RevPorAno/1934/1934Tapuias.pdf Acesso em: 01 fev. 2008.

PROUS, A. 1992. Arqueologia brasileira. Brasília: Editora Universidade de Brasília.

PUNTONI, P. 1998. A Guerra dos Bárbaros: povos indígenas e a colonização do sertão Nordeste do Brasil, 1650-1720. Tese de Doutorado, Programa de Pós-Graduação em História Econômica e História Social, Universidade de São Paulo, São Paulo.

QUEIROZ, A. N.; CARDOSO, G. M. B. 1996. "Nota prévia sobre a fauna holocênica de vertebrados do sítio arqueológico "Pedra do Alexandre", Carnaúba dos Dantas-RN, Brasil". Clio: Série Arqueológica, Recife, v. 1 (11), 137-140. Disponível em: https://periodicos.ufpe.br/revistas/clioarqueologica/article/view/247085 Acesso em: 09 jul. 2020. 
RIBEIRO, M. S. 2007. Arqueologia das práticas funerárias: uma abordagem historiográfica. São Paulo: Alameda.

SANTORO, C. M.; STANDEN, V. G.; ARRIAZA, B. T.; DILlEHAY, T. D. 2005. "Archaic funerary pattern or posdepositional alteration? the patapatane burial in the highlands of South Central Andes". Latin American Antiquity, [s.i.], v. 16 (3), 329-346. Disponível

em:

http://ink.galegroup.com/apps/doc/A137362414/AONE? $\mathrm{u}=$ googlescholar\&sid=AONE\& xid=7ee91fdf Acesso em: 05 set. 2018.

TAINTER, J. R. 1980. "Behavior and status in a middle Woodland mortuary population from Illinois Valley”. American Antiquity, [s.i.], v. 45 (2), 308-313.

SANTOS, A. A. S. 1997. Paleopatologia do Sítio Pré-Histórico Pedra do Alexandre Carnaúba dos Dantas - RN, Brasil: avaliação epistemológica, radiológica e histopatológica. Tese de Doutorado, Programa de Pós-Graduação em História. Universidade Federal de Pernambuco, Recife.

SANTOS, M. B. 2009. Práticas mortuárias entre povos indígenas no Pantanal MatoGrossense: Arqueologia, Etno-história, Etnologia. Dissertação de Mestrado, Programa de Pós-Graduação em História, Universidade Federal da Grande Dourados. Dourados. Disponível em: https://www.ppghufgd.com/wp-content/uploads/2017/06/Matias-Belidodos-Santos.pdf Acesso em: 09 jul. 2020.

SANTOS JÚNIOR, V. 2008. Os índios Tapuias do Rio Grande do Norte: antepassados esquecidos. Mossoró: Fundação Vingt-un Rosado.

SANTOS JÚNIOR, W. G. 2013. Enterramentos pré-históricos do sítio Pedra do Alexandre, na área arqueológica do Seridó - RN. Monografia, Departamento de Arqueologia, Universidade Federal de Pernambuco, Recife.

SAXE, A. A. 1970. Social dimension of mortuary practices. Tese de Doutorado, University of Michigan, Michigan.

SCHLANGER, S. H. 1992. "Recognizing persistent places in Anasazi settlement systems". In: ROSSIGNOL, J.; WANDSNIDER, L. (Eds.). Space, time, and archaeological landscapes. New York: Plenum Press, 91-112. 
SILVA, D. C. 2004. Práticas funerárias na Pré-História do Nordeste do Brasil. Dissertação de Mestrado, Programa de Pós-Graduação em História, Universidade Federal de Pernambuco, Recife.

SILVA, J. V. 2018. Estudo de indicadores de canibalismo na área arqueológica do Seridó: ossos humanos alterados do Sítio Furna do Umbuzeiro, Carnaúba dos Dantas, RN, Brasil. Dissertação de Mestrado, Programa de Pós-Graduação em História, Universidade Federal de Pernambuco, Recife. No prelo.

SILVA, S. F. S. M.; SOLARI, A.; MARTIN, G. 2020. "Sítio arqueológico Pedra do Alexandre, Seridó, Rio Grande do Norte: principais resultados de estudos, os sepultamentos e perspectivas para o futuro". Clio: Série Arqueológica, Recife: Editora Universitária UFPE.

SILVA, S. F. S. M.; LAVALLE, H. S.; OLIVEIRA, A. P. 2013(a). Relatório da $16^{\text {a }}$ Etapa de Campo do Sítio Pré-histórico Pedra do Alexandre, Carnaúba dos Dantas, RN: remanescentes ósseos humanos e seus acompanhamentos e materiais associados. Relatório Técnico do Laboratório de Arqueologia Biológica e Forense (LABIFOR/UFPE). Recife: Universidade Federal de Pernambuco.

SILVA, S. F. S. M.; LAVALLE, H. S.; OLIVEIRA, A. P. 2013(b). Relatório das $16^{\mathrm{a}}$ e $17^{\mathrm{a}}$ Etapas de Campo do Sítio Pré-histórico Pedra do Alexandre: dados qualitativos e quantitativos dos remanescentes humanos. Relatório Técnico do Laboratório de Arqueologia Biológica e Forense (LABIFOR/UFPE). Recife: Universidade Federal de Pernambuco.

SOLARI, A.; MARTIN, G.; SILVA, S. F. S. M. 2016(a). “A presença infantil no registro bioarqueológico no sítio Pedra do Alexandre, Carnaúba dos Dantas, RN, Brasil”. FUMDHAMentos, São Raimundo Nonato/PI, v. 13, 4-30. Disponível em: http://www.fumdham.org.br/wp-content/uploads/2017/04/ana-solari-martin.pdf?x49464 Acesso em: 05 set. 2018.

SOLARI, A.; MARTIN, G.; SILVA, S. F. S. M. 2016(b). "Estudos de Antropologia dental na população do sítio arqueológico Pedra do Alexandre, Carnaúba dos Dantas, RN (9.000 a 2.000 AP)". Clio: Série Arqueológica, Recife, v. 31 (2), 14-57. Disponível em: 
https://periodicos.ufpe.br/revistas/clioarqueologica/article/download/246495/35544 Acesso em: 05 set. 2018.

SOLARI, A.; PESSIS, A. M.; MARTIN, G.; SILVA, S. F. S. M. 2018. "Patologias invisíveis na Bioarqueologia da infância". Revista de Arqueologia, [s.i.], v. 31 (2), 103117. Disponível em: https://revista.sabnet.org/index.php/SAB/article/view/587 Acesso em: 05 set. 2018.

SOUZA, S. M.; RODRGUES-CARVALHO, C. 2013. "Ossos no chão: para uma abordagem dos remanescentes humanos em campo". Boletim do Museu Paraense Emílio Goeldi, Belém, v. 8 (3), 551-566. Disponível em: https://www.scielo.br/pdf/bgoeldi/v8n3/05.pdf Acesso em: 09 jul. 2020.

STRAUSS, A; M. 2010. As práticas mortuárias dos caçadores-coletores pré-históricos da região de Lagoa Santa (MG): um estudo de caso do Sítio Arqueológico "Lapa do Santo". Dissertação de Mestrado, Universidade de São Paulo, São Paulo.

SULLASI, H. S. L.; SANTOS, A. L. C.; SILVA, S. F. S. M. 2018. "Bone Diagenesis Study of the Burials from the Pedra do Alexandre Archaeological Site, Carnaúba dos Dantas, Rio Grande do Norte, Brazil". Revista Cadernos do Lepaarq, Pelotas/RS, v. 15 (30), 162-178. Disponível em: https://periodicos.ufpel.edu.br/ojs2/index.php/lepaarq/article/view/12955 Acesso em: 05 set. 2018.

TAINTER, J. R. 1980. "Behavior and status in a middle Woodland mortuary population from Illinois Valley”. American Antiquity, [s.i.], v. 45 (2), 308-313.

TAINTER, J. R. 1981. "Replay to 'A critique of some recent North American mortuary studies"”. American Antiquity, [s.i.], v. 46 (2), 416-420.

TEENSMAN, B. N. 2000. "O diário de Rodolfo Baro (1647) como monumento aos índios Tarairiú do Rio Grande do Norte". In: ALMEIDA, L. S.; Galindo, M; ELIAS J. L. Índio do Nordeste: temas e problemas, volume II. Maceió: EDUFAL, 81-99.

TORRES, A C. "Estudos dos pigmentos do sítio pré-histórico Pedra do Alexandre Carnaúba dos Dantas - RN". Clio: Série Arqueológica, Recife, v. 1, n. 11, 59-70, $1995-$ 1996. 
VIDAL, I A. 2002. "Projeto Arqueológico do Seridó: Escavação no Sítio Pedra do Chinelo, Parelhas, RN, primeiros resultados”. Clio: Série Arqueológica, Recife, v.1 (15), 157-169.

WALTHALL, J. A. 1999. "Mortuary behavior and early Holocene land use in the North American midcontinent". North American Archaeologist, [s.i.], v. 20 (1), 1-30. Disponível em: http://journals.sagepub.com/doi/abs/10.2190/MDEP-VM2K-YB2Q-L1D0. Acesso em: 05 set. 2018. 